Boletín de la Sociedad Geológica Mexicana

VOLUMEN 62, NÚM. 3, 2010, P. 399-436

\title{
Late Holocene Paleoenvironmental History of the Upper West Amarillo Creek Valley at Archaeological Site 41PT185/C, Texas, USA
}

\author{
Manuel R. Palacios-Fest ${ }^{1, *}$ \\ ${ }^{1}$ Terra Nostra Earth Sciences Research, LLC, Tucson, AZ 85740-7195, U.S.A \\ *mrpalacios@tnesr.com
}

\begin{abstract}
In combination, microinvertebrates, calcareous algae (Charophyta), and the stable isotopes from ostracodes and gyrogonites (the calcareous remains of charophytes) are a powerful tool for reconstructing paleoclimates. This study compares the paleoenvironmental signatures of land and aquatic mollusks, ostracodes, and charophytes with stable-isotope $\left(\delta^{18} \mathrm{O}\right.$ and $\left.\delta^{13} \mathrm{C}\right)$ values for Cypridopsis sp. (an ostracode) and the gyrogonites of Chara globularis and Nitella flexilis. Each individual signature contributes its own evidence of environmental change between $1890 \pm 40$ years B.P. and post $-750 \pm 40$ years B.P. at archaeological site 41 PT185/C in northern Texas, United States of America. The interpretation of the combined data permits a detailed reconstruction of paleoclimatic variability at the transition from the Medieval Climatic Anomaly to the Little Ice Age, allowing inferences about the impact of such environmental change on human populations in this part of the U.S. Southwest.
\end{abstract}

Keywords: Microinvertebrates, gyrogonites, archaeology, paleoclimate, Medieval Climatic Anomaly, Little Ice Age.

\section{Resumen}

En combinación, los microinvertebrados, algas calcáreas (Charophyta), e isótopos estables de ostrácodos y girogonitos (los restos calcáreos de carófitas) constituyen una herramienta muy poderosa para reconstruir paleoclimas. Este estudio compara las firmas paleoambientales de moluscos terrestres y acuáticos, ostrácodos, y carófitas con los valores de los isótopos estables $\left(\delta^{18} O\right.$ y $\left.\delta^{13} C\right)$ obtenidos de Cypridopsis sp. (un ostrácodo) y los girogonitos de Chara globularis y Nitella flexilis. Cada una de ellas contribuye con su propia evidencia sobre el cambio ambiental ocurrido entre $1890 \pm 40$ A.P. y después de $750 \pm 40$ A.P. en el sitio arqueológico 41PT185/C en el norte de Texas, Estados Unidos de América. La combinación interpretativa de los datos permite una reconstrucción detallada de la variabilidad paleoclimática durante la transición de la Anomalía Climática Medieval a la Pequeña Edad del Hielo, que permite inferir el impacto que dicho cambio tuvo sobre las poblaciones humanas en esta parte del Sudoeste de los Estados Unidos.

Palabras clave: Microinvertebrados, girogonitos, arqueología, paleoclima, Anomalía Climática Medieval, Pequeña Edad del Hielo. 


\section{Introduction}

The reconstruction of ancient aquatic environments associated with human settlements allows paleolimnologists, geomorphologists, and geoarchaeologists to understand both local and regional processes of environmental and climatic change, as well as the impact such change may have had on human populations. The Texas Panhandle contains a rich record of human occupation and sedimentation spanning the past 11500 years (Johnson and Holliday, 2004). The paleontological and paleobotanical remains in the sediments provide evidence of the environmental history of the region. Numerous prehistoric sites are situated in the Texas Panhandle, including the Upper West Amarillo Creek Valley near Amarillo, where single- and multiple-occupation localities were identified by Haecker (1999). Five prehistoric sites (41PT184, 41PT185/C, 41PT186, 41PT187, and 41PT245) were considered potentially eligible for listing in the National Register of Historic Places (Haecker, 1999; Quigg et al., 2008). Several multiple-occupation sites with good stratigraphic context have provided useful information on the stratigraphy, depositional environments, and paleoenvironments throughout the Holocene, including small lake basins and marshes (e.g., Howard, 1935; Cotter, 1937; Sellards, 1952; Wendorf, 1961; Wendorf and Hester, 1975; Caran, 1991).

The paleoecology of marshes is poorly known compared with that of lacustrine environments. Reconstructing the aquatic environment of a marsh discovered in the Upper West Amarillo Creek Valley during geoarchaeological exploration is of major significance because it will allow specialists to understand the environmental background that affected northwestern Texas during the late Holocene. In this study, ostracodes (microcrustaceans), mollusks, and the gyrogonites (fertilized female gametangia) of calcareous algae are used to interpret the history of the marsh. In addition, stable isotopes $\left(\delta^{18} \mathrm{O}\right.$ and $\left.\delta^{13} \mathrm{C}\right)$ from ostracodes and gyrogonites are used to integrate a detailed paleoenvironmental history of the area.

Ostracodes are microscopic crustaceans characterized by a hinged bivalve carapace made of calcite and ranging in size between 0.5 and $2 \mathrm{~mm}$. The carapace is the only body part that is preserved in the geologic record (Pokorný, 1978; Horne et al., 2002). In continental waters they are mostly benthic, although some species are nektic and may swim around the vegetation (Forester, 1991). This group colonized continental aquatic systems as early as the Carboniferous but has thrived in the oceans since the Cambrian. Today, ostracodes are diverse and abundant in marine and nonmarine environments. Paleontologists have devoted more time to the study of ostracodes than have biologists - hence the poorly understood ecology of ostracodes. Recent progress on the application of ostracodes as indicators of hydrogeologic variations, however, calls for additional studies of the ecology of springs and seeps, as well as their associated wetlands or cienegas (De Deckker,
1983; Forester, 1983, 1986; Palacios-Fest, 1994, 2008; Palacios-Fest et al., 1994, 2001; Holmes and Chivas, 2002).

Mollusks include the bivalve clams and mussels (Bivalvia) and the univalve snails (Gastropoda). Mollusks are soft bodied and unsegmented, with a body organized into a muscular foot, a head region, a visceral mass, and a fleshy mantle that secretes a shell of proteinaceous and crystalline calcium carbonate (aragonite) materials. Both marine and nonmarine species exist. The nonmarine species, which are the subject of this study, include several families of snails (the aquatic Planorbidae, Ancylidae, and Lymnaeidae and the terrestrial Pupillidae) and at least one family of clams (Pisidiidae). The associations of mollusks in the sediments reflect the water quality, salinity, and streamflow (Rutherford, 2000; Dillon and Stewart, 2003). For example, the occurrence of juveniles alone in a sample is interpreted as the introduction of early-stage individuals during warm or warming months (Rutherford, 2000). If the population reaches stability and adults are encountered, then it is assumed that the feature held water for a relatively prolonged period. Some species, like Pisidium sp. and Ferrissia hendersoni, require well-oxygenated, lotic (flowing) waters and prefer neutral to alkaline $\mathrm{pH}$ but cannot tolerate organic pollution present in the marsh. By contrast, other species, like Planorbella scalaris and Physella virgata, can tolerate poorly oxygenated (but not disoxic), lentic (standing) waters and can tolerate some organic pollution and eutrophic conditions (Dillon and Stewart, 2003). The latter species prefer lakes, wetlands, ponds, and the calmest areas of coastal rivers. Like the ostracode signatures, the signatures of mollusks are used in this study to integrate the paleoecological characteristics of the Upper West Amarillo Creek Valley marsh (site 41PT185/C, Unit D).

In addition to microinvertebrates, the gyrogonites (calcareous remains) of the algae Chara and Nitella may be used to reconstruct the alkalinity, time of colonization, and paleohydraulics of the marsh. Charophytes are small, branching algae normally living in carbonate-rich freshwater. Modern examples are known as stoneworts because they have a partial carbonate skeleton. They look like small, subaqueous horsetails. The Characeae or Charophyta are a strange, isolated group of aquatic plants growing entirely underwater. Modern species prefer ponds or lakes, although they are occasionally found in running water, and are partial to somewhat brackish conditions, such as freshly dug ditches in marshes near the sea. In deeper environments subject to inundation, they soon give way to more vigorous vegetation like cattails (Typha). They commonly pioneer the colonization of habitats such as recently dug canals and ditches (Allen, 1950).

Ecologically, the Charophyta promote water clarity, enhance fish populations, and stabilize the bottom surface. In clear, still water, masses of orange-red antheridia (the male reproductive organs) are abundant and visible (Allen, 1950). The average height of these plants is $30-46 \mathrm{~cm}$, but some individuals are just a few centimeters tall. Usually, 
charophytes grow in shallow waters (less than $60 \mathrm{~cm}$ deep), but sometimes they occur at much greater depths (Allen, 1950). Many modern charophytes have a short season between spring and late summer, just before the aquatic system dries out, and when temperatures are warm (Allen, 1950). Gyrogonites are used in this study to complement the microinvertebrate record.

Stable-isotope $\left(\delta^{18} \mathrm{O}\right.$ and $\left.\delta^{13} \mathrm{C}\right)$ geochemistry based on ostracode valves and the gyrogonites of Charophyta is another approach to paleoclimatic reconstructions. Lister (1988) and Eyles and Schwarcz (1991), followed by numerous other researchers (e.g., Lewis et al., 1994; von Grafenstein et al., 2000; Wrozyna et al., 2010), have pursued the utility of carbon and oxygen isotopes in ostracodes for these reconstructions. The isotopic record from ostracode valves allowed these investigators to establish the rate and timing of climate change across space. For example, Lister (1988) determined the Alpine deglaciation, Holocene climatic changes, and changing lacustrine productivity of Lake Zürich, whereas Wrozyna et al. (2010) utilized stable isotopes to identify lake-level changes in Lake Nam Co, southern Tibet, during the past 600 years. Stable-isotope studies of ostracodes have proved their significance in paleoenvironmental reconstructions; calcareous algae, however, have been little explored.

In recent years, interest in the applicability of stableisotope analysis of calcareous algae has grown at a fast pace, encouraging researchers to analyze modern Charophyta in order to develop an analog for the geologic record. Coletta et al. (2001), Andrews et al. (2004), and Pentecost et al. (2006) have focused on the study of modern calcareous algae, including stems and gyrogonites, to establish trends in carbon and oxygen biofractionation in an attempt to use them in paleoecological reconstructions. Becker et al. (2002) conducted one of the first applications of these results to a geological example from a late Oligocene-early Miocene lake in Switzerland (Brochene Fluh section). These authors demonstrated that, during the late Oligocene, the lake was a closed basin subject to seasonal changes that gradually diminished, perhaps as the result of the ingression of the Burdigalian Sea.

The purpose of this investigation is to combine routine paleoecological analysis of microinvertebrates and calcareous algae with the stable-isotope geochemistry $\left(\delta^{18} \mathrm{O}\right.$ and $\delta^{13} \mathrm{C}$ ) of ostracodes and gyrogonites to reconstruct the late Holocene environmental history of the Upper West Amarillo Creek Valley marsh at Unit D.

\section{Area of study}

The Upper West Amarillo Creek Valley is a small canyon cut into the Ogallala Formation, the source of the High Plains Aquifer. It is located on the south side of the Canadian River (Figure 1a). In this area the Ogallala Formation rests unconformably upon Triassic sandstones and shales of the
Trujillo and Tecovas Formations. The prehistoric Pipeline site 41PT185/C, spanning three meanders of West Amarillo Creek at the Landis Property, is on the valley floor near Amarillo, Texas. During the initial survey the site was divided into two loci (A and B), one on each side of West Amarillo Creek (Haecker, 1999). Locus A is defined as the middle meander and lies on the right bank of the creek. A spring emanates from the creek bank about $100 \mathrm{~m}$ south of the site. Locus A lies in alluvial deposits on the eastern side and is bisected by a helium-gas line. The gradually sloping terrace is covered in dense grasses; trees border the creek. A small cluster of quartzite cobbles is eroding from the terrace edge on the southern side. A fragment of a bison bone from adjacent Feature 1 at $10 \mathrm{~cm}$ below ground surface (bgs) yielded a radiocarbon date of $2130 \pm 40$ B.P. (Beta135417). Locus B is located on the left bank of the creek near the point where the helium pipeline crosses the creek; it is situated on the northernmost of the three meanders very close to the Girl Scout cabins.

Frederick (2008) described a complex Holocene alluvial history in which six allostratigraphic units (A through F) have been recognized in the area (Figure 1b). Unit D (Figure 2), the source of materials for the present study, overlies the coarse-sand Unit C and underlies Unit $\mathrm{E}$, which is characterized by coarse sediments indicating large flood events. (Units $\mathrm{C}$ and $\mathrm{E}$ are not included in this study.) Unit D consists of more than $4.5 \mathrm{~m}$ of fine-grained dark-colored mud, which appears to represent a period of presumably more-humid climate, when small ponds and marshes dominated the floor of the West Amarillo Creek Valley (Figure 2a).

The samples used for this study were obtained from Trench BT36, the most complete record from Unit D (Figure $2 \mathrm{~b}$ ). The base of the unit was more than $5 \mathrm{~m}$ bgs and was not uncovered by the trench. The period represented by Unit $D$ appears to have lasted a little more than 1000 years, from roughly 1900 years B.P. to sometime after 800 years B.P. (Appendix 1; see geochronology in section 4.1, and in Frederick, 2008).

Floodplain facies of Unit D appear to be massive cumulic soils more than $3 \mathrm{~m}$ thick that exhibit little lithologic variation until relatively late in the history of this deposit, when coarse material, specifically gravel, appears to become more common. Toward the end of Unit D's deposition, West Amarillo Creek appears to have experienced more and larger floods, which resulted in an increase in the size of the stream deposits and eventually prompted a period of channel incision. Sometime at or after $c a .800$ years B.P., the creek channel incised about $4 \mathrm{~m}$, and our existing radiocarbon dates suggest that it began filling this cut only sometime around 430 years ago. The resulting deposit, Unit E, remains part of the modern floodplain but appears to be flooded infrequently today. Hence, at Trench BT36, Unit $\mathrm{E}$ overlies unconformably on Unit D (dashed line in Figure 2b).

In addition to the dates obtained from site 41PT185/C, 


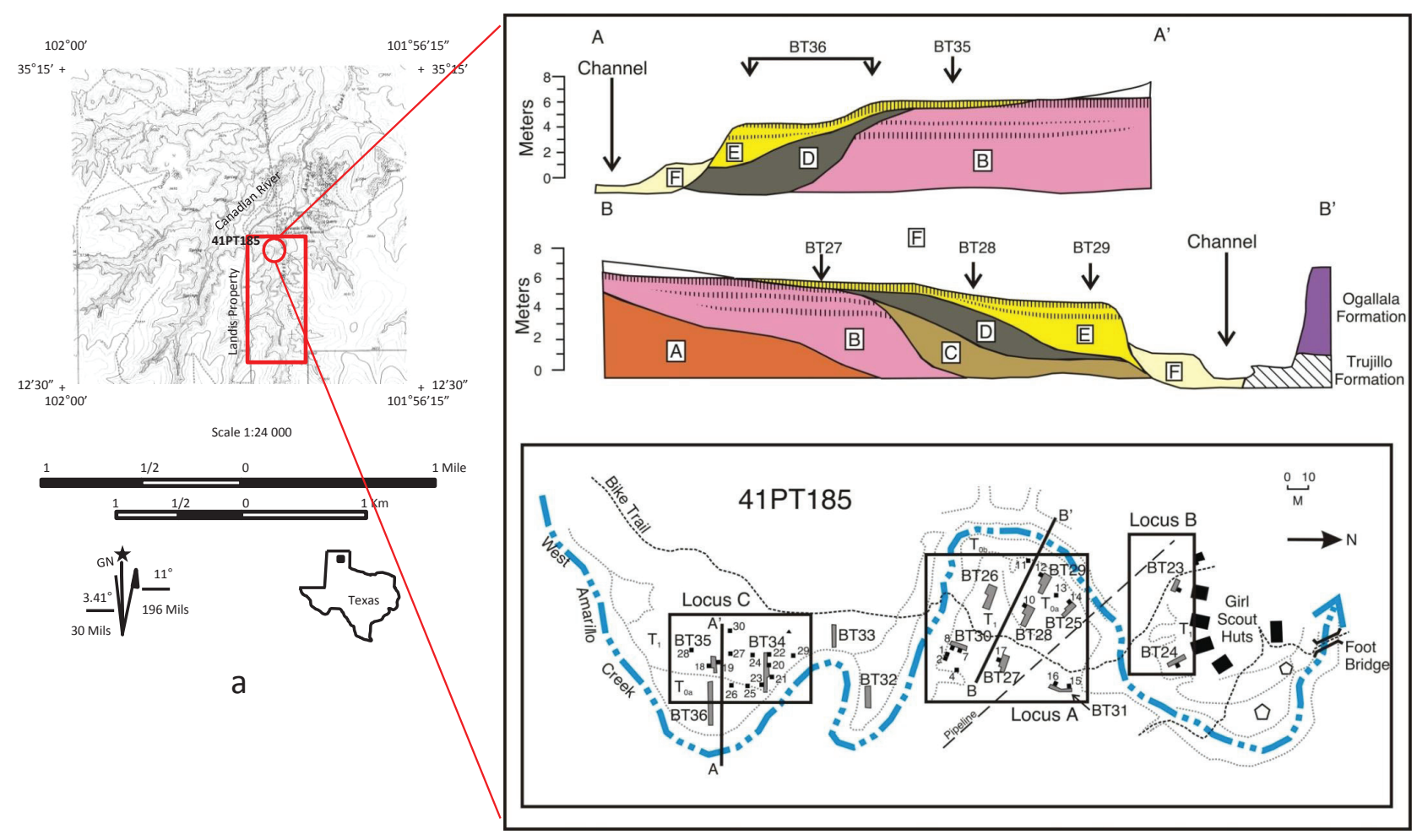

Figure 1. Location map of the Upper West Amarillo Creek Valley in the Texas Panhandle (after Quigg, 2008): (a) general location; (b) plan view of site 41PT185/C showing location of Trench BT36 (oval) and cross section of the six allostratigraphic units recorded by Frederick (2008) within site 41PT185/C (after Frederick, 2008).

one from site 41PT245 was extrapolated to propose the environmental history of Unit D (Section 4.1).

\section{Materials and methods}

Twenty-four sediment samples from two sets were analyzed for microinvertebrates and calcareous algae. Nineteen of them provided information on ostracodes, mollusks, and gyrogonites to reconstruct the paleoenvironmental history of the Upper West Amarillo Creek Valley. In addition, five large flotation samples were analyzed for mollusks to integrate the paleoecological record of the marsh. The samples were in stratigraphic sequence and were prepared using routine procedures (Forester, 1988) modified by Palacios-Fest (1994). Samples were air-dried, weighed, and soaked in boiling distilled water with $1 \mathrm{~g}$ of Alconox to disaggregate the sediments. Then they were left to sit at room temperature for five days and were stirred once a day during that period. With a set of three sieves, the samples were wet-sieved to separate the coarse $(>1 \mathrm{~mm})$, medium $(106 \mu \mathrm{m}-1 \mathrm{~mm})$, and fine $(63-105 \mu \mathrm{m})$ sand fractions to help identify the system's paleohydraulics. The three finest fractions (very fine sand, silt, and clay) were discarded during the washing process.
Therefore, the particle-size analysis departs from the formal United States Department of Agriculture (USDA) procedure (USDA, 2003: 207-209), and it is used only as a rough reference in this study. It is important to highlight that the possible discrepancy between the approach used in this investigation and that used by the USDA is the result of grouping the very fine sands with the finer fractions. This procedure in this study affects the total percentage of sand but does not affect the actual behavior of sands in the ecosystem. The value of the approach used here is that it provides a quick and easy way to process the data and to estimate the patterns of water discharge into the marsh over time. The data and geochronology are shown in Appendix 1.

All samples were analyzed under a low-power microscope to identify fossil contents and faunal assemblages. Ostracodes, mollusks, and/or gyrogonites were present in all samples (Appendix 2). All 24 samples contained mollusks (Appendices 3 and 4). Sixteen samples contained ostracodes (Appendices 5 and 6) and 15 contained gyrogonites (Appendices 7 and 8). Ostracodes and gyrogonites were observed but not counted in the five flotation samples. Total and relative abundances were recorded for the sediment samples. Based on Delorme $(1969,1989)$, values for the standard taphonomic variables of fragmentation, abrasion, disarticulation (carapace/valve [C/V] ratios), and adulthood 


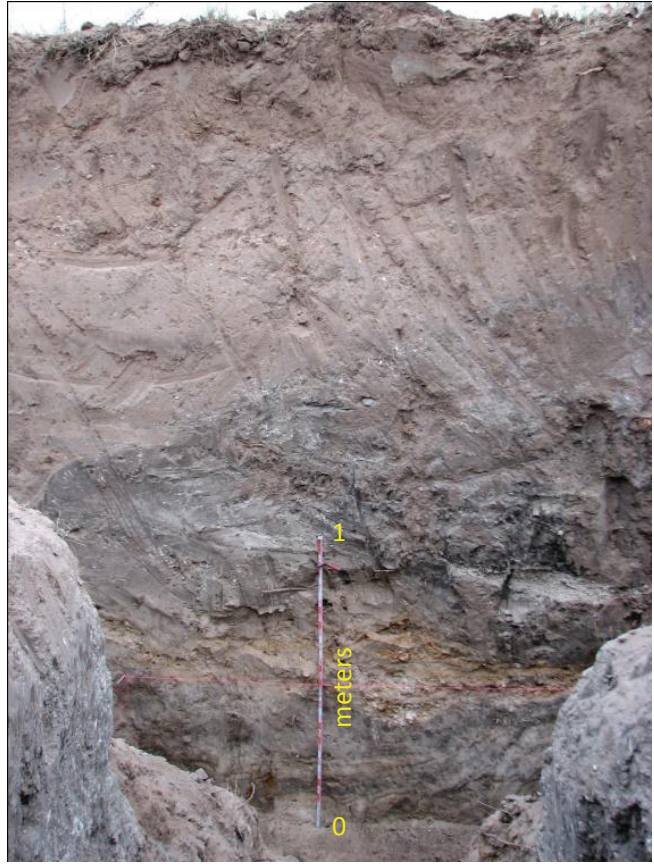

a

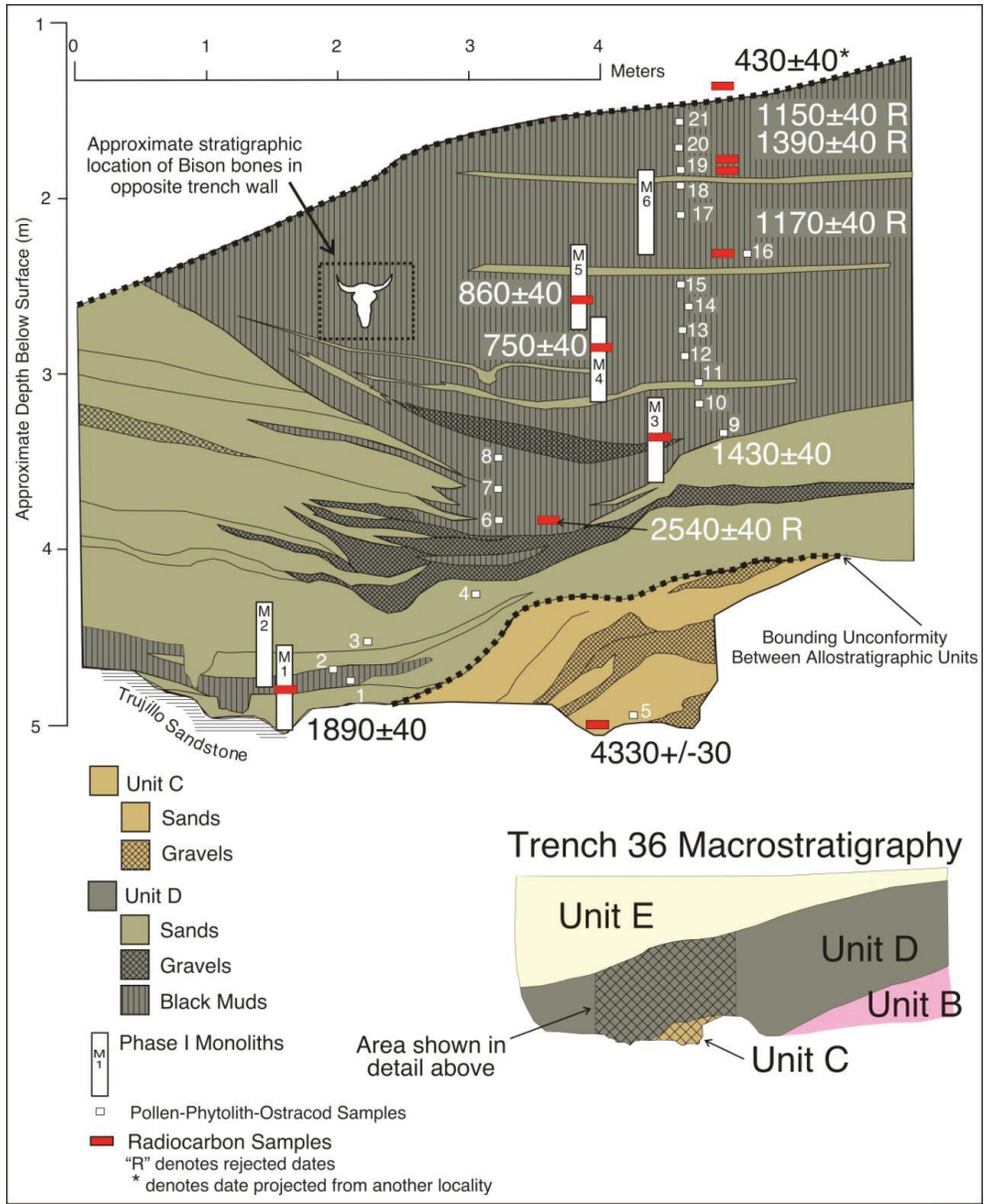

Figure 2. Trench BT36: (a) photo of profile; (b) stratigraphy and geochronology of Unit D. After Frederick (2008).

(adult/juvenile $[\mathrm{A} / \mathrm{J}]$ ratios) were recorded to establish the synecology (ecology of the communities) as opposed to the autoecology (ecology of single species) of the ecosystem (Adams et al., 2002). Autoecology, however, was used to integrate the environmental framework. The specimens were placed on micropaleontological slides or in acrylic boxes and saved in the Terra Nostra Earth Sciences Research, LLC, collection.

Taphonomic variables were used to recognize degrees of transport and/or burial characteristics like desiccation and sediment compaction. The rates of fragmentation, abrasion, and disarticulation are realistic indicators of transport; commonly, these variables show increasing damage with increasing transport. One must be cautious in using this criterion, but the nature of the deposits suggests that the taphonomic characteristics of recovered microinvertebrates may reflect the marsh's hydraulic properties. Other features like encrustation and coating were used to determine authigenic mineralization and stream action, respectively. The redox index and the color of valves reflected burial conditions. The $\mathrm{A} / \mathrm{J}$ and $\mathrm{C} / \mathrm{V}$ ratios were used as indicators of biocenosis (Whatley, 1983; Palacios-Fest et al., 2001).
For example, Brouwers (1988) indicated that the ideal tanathocenosis should be composed of a 1:8 adult:juvenile ratio, as ostracodes shed their skeletons eight to nine times. Juvenile valves, however, are more fragile than those of adults and are more susceptible to the physical and chemical effects of weathering, modifying that ratio to $1: 5$ or 1:6 (Brouwers, 1988). Whatley (1983), on the other hand, describing the effects of transport and burial, concluded that abundant disarticulated valves indicate natural burial conditions, whereas an abundance of carapaces indicates fast (catastrophic) deposition and burial, preventing the valves from separating. These taphonomic criteria may be applied to ostracodes and clams, and to a lesser extent to snails.

Fifty-two pristine valves of Cypridopsis vidua and Cypridopsis okeechobei, two of the most common ostracodes in the marsh, were selected for stable-isotope $\left(\delta^{18} \mathrm{O}\right.$ and $\left.\delta^{13} \mathrm{C}\right)$ analysis, along with 71 specimens of Chara globularis and Nitella flexilis, the most abundant gyrogonites recovered from the site. In most cases, two replicates, grouped by species, were analyzed for each stratigraphic interval (Appendices 9 and 10). The specimens were thoroughly cleaned with $M \Omega 18$ water and a fine brush (000) and then 
submitted for stable-isotope analysis to the Environmental Isotope Laboratory at the University of Arizona. Oxygen and carbon stable-isotope ratios were measured with an automated carbonate-preparation device (Kiel III) coupled to a gas-ratio mass spectrometer (Finnigan MAT 252). Samples were reacted with dehydrated phosphoric acid under vacuum at $70^{\circ} \mathrm{C}$. The isotope ratio measurement is calibrated based on repeated measurements of NBS-19 and NBS-18; precision is $\pm 0.1 \%$ for $\delta^{18} \mathrm{O}$ and $\pm 0.06 \%$ for $\delta^{13} \mathrm{C}$ (one sigma). Five replicates of Cypridopsis sp. (samples 74, 76 , and 82 ) produced questionable data, but a low-voltage correction factor was applied to generate reliable values. The corrected values shown in Appendix 9 have an uncertainty of $\pm 0.2 \%$ (Dettman, personal communication), suggesting that the data are viable. Isotopic data for calcites are reported in delta notation relative to the VPDB international scale (Coplen, 1994).

Qualitative indexes were prepared for mollusks, ostracodes, and calcareous algae, each indicating some particular attributes of the environment. For example, the paleoenvironmental index (PI) for mollusks groups the species into aquatic and terrestrial clusters. Current literature was used to identify the mollusk species and their ecological requirements (Webb, 1942; Eversole, 1978; Dillon, 2000; Rutherford, 2000; Sharpe, 2002; Dillon and Stewart, 2003). The equation used to calculate PI in this study is as follows:

$$
\mathrm{PI}=(\Sigma \% \text { terrestrial species })-(\Sigma \% \text { aquatic species })
$$

The index positively weights the terrestrial species and negatively weights the aquatic species. The resulting value is dimensionless, indicating only the environmental variation from terrestrial to aquatic conditions.

The qualitative salinity index (SI) for ostracodes takes into consideration the salinity tolerance of the species present in the marsh, based on our current knowledge of their ecological requirements as presented in the North American Non-Marine Ostracode Database (Forester et al., 2005) and other references (Delorme, 1989; Palacios-Fest, 1994; Curry, 1999). The equation used to calculate SI in the present study is as follows:

$\mathrm{SI}=[8(\%$ Physocypria globula $)+7(\%$ Candona patzcuaro $)+6(\%$ Fabaeformiscandona caudata $)+$ $5(\%$ Cypridopsis vidua $)+4(\%$ Ilyocypris bradyi $)+$ $3(\%$ Herpetocypris brevicaudata $)+2(\%$ Potamocypris smaragdina $)+(\%$ Pseudocandona stagnalis $)]-[(\%$ Darwinula stevensoni $)+2(\%$ Eucypris meadensis $)+3(\%$ Limnocythere floridensis $)+4(\%$ Physocypria pustulosa $)+$ $5(\%$ Cypria ophthalmica $)+6(\%$ Cavernocypris wardi $)+$ 7(\% Cypridopsis okeechobei $)]$

The index positively weights species with incrementally higher salinity tolerances and negatively weights species with incrementally lower salinity tolerances. A dimensionless value is generated by this equation, providing the likely trends in water salinity over time.

The ecological requirements of calcareous algae are used in this study to generate an alkalinity index (AI), using the same model as for mollusks and ostracodes. The equation for the members of the Charophyta is as follows:

$\mathrm{AI}=[2(\%$ Chara globularis $)+\%$ Chara filiformis $]-(\%$ Nitella flexilis)

The index positively weights species with incrementally higher $\mathrm{pH}$ tolerances and negatively weights species with incrementally lower $\mathrm{pH}$ tolerances. As indicated in Appendix 7, the alkalinity range for calcareous algae is 7.5-10.5 (Coletta et al., 2001; Andrews et al., 2004; Pentecost et al., 2006). The qualitative, dimensionless value of the alkalinity index indicates the $\mathrm{pH}$ variation within the known range for the species involved.

Aquatic microinvertebrates and calcareous algae inhabit waters of different hydrochemical composition; at the species level, many are very sensitive to water chemistry. Ostracode, mollusk, and calcareous algae assemblages can be used to recognize the three major water types defined by Eugster and Hardie (1978):

Type I: Water dominated by $\mathrm{Ca}^{2+}, \mathrm{Mg}^{2+}$, and $\mathrm{HCO}_{3}^{-}$; typically freshwater or very low salinity conditions.

Type II: Water enriched in $\mathrm{Ca}^{2+}$ and depleted in $\mathrm{HCO}_{3}^{-}$; additionally contains the combinations of $\mathrm{Na}^{+}, \mathrm{Mg}^{2+}, \mathrm{SO}_{4}^{2^{-}}$, or $\mathrm{Na}^{+}, \mathrm{Mg}^{2+}, \mathrm{Cl}^{-}$; ranges from low salinity to hypersaline conditions.

Type III: Water depleted in $\mathrm{Ca}^{2+}$ and enriched in $\mathrm{HCO}_{3}^{-}$and $\mathrm{CO}_{3}{ }^{2-}$ (i.e., alkaline-enriched); usually contains combinations of $\mathrm{Na}^{+}, \mathrm{Mg}^{2+}, \mathrm{Cl}^{-}$, or $\mathrm{Na}^{+}, \mathrm{Mg}^{2+}, \mathrm{SO}_{4}^{2-}$; ranges from low salinity to hypersaline conditions.

The application of this model to paleoenvironmental reconstructions is, to the best of my knowledge, better known for ostracodes. This spectrum clearly shows that water chemistry plays a major role in the geographic distribution of ostracodes. In addition to water chemistry, temperature is another factor that affects the distribution of these organisms, as the latitudinal distribution of ostracodes demonstrates. Many species respond to temperature through both reproductive and survival ability (Delorme and Zoltai, 1984; Forester, 1987; De Deckker and Forester, 1988). For example, Cytherissa lacustris is limited to water temperatures lower than $23{ }^{\circ} \mathrm{C}$ and is common in subpolar regions, whereas Limnocythere bradburyi is restricted to warm temperatures of low to midlatitudes (Delorme, 1978; Forester, 1985). Their sensitivity to temperature makes ostracodes very useful for paleoclimate reconstructions (Cohen et al., 2000; Palacios-Fest, 2002). Once the ecological requirements of ostracodes are determined, it is possible to reconstruct paleoenvironments from the geologic record (Delorme, 1969; Palacios-Fest, 1994; Holmes and Chivas, 2002). 


\section{Results}

\subsection{Age control and sedimentary record}

As mentioned earlier, Frederick (2008) described the stratigraphy of the Upper West Amarillo Creek Valley. In brief, six episodes of alluviation-namely, Units A through F-formed the West Amarillo Creek Valley. Using a composite model, Frederick (2008) speculated on the origin and evolution of each unit (upper part of Figure 1b). In this study, Unit D, where the aquatic system developed, is the center of interest. Unconformably overlying Unit C, a very distinctive deposit consisting of black (10YR 2/1) to dark grayish brown (10YR 4/2) or light brownish gray (10YR 6/2) silty sand to silty clay forms Unit D (Appendix 1). It is more than $4.5 \mathrm{~m}$ thick, representing a period of presumably more-humid climate that allowed the formation of small ponds and marshes in the area. The episode lasted slightly more than 1000 years. Unit D is unconformably capped by Unit E.

The geochronology is based on four radiocarbon dates obtained from Unit D and one at the base of Unit $\mathrm{E}$ from site 41PT245 (Figure 2b; Appendix 1). The most recent date is considered an indication that alluviation of Unit $\mathrm{D}$ ended before this time. The most detailed record was obtained from Trench BT36, which exposed a series of superimposed channels associated with the unit. As noted in the Section 2 (area of study), the base of the unit was more than $5 \mathrm{~m}$ bgs and was not completely exposed during excavation of the trench. The earliest phase of sedimentation started sometime before $1890 \pm 40$ years B.P. (Beta-210070), a period characterized by more than $50 \%$ calcium carbonate deposited on the valley floor. The middle of the unit was dated to $1430 \pm 40$ years B.P. (Beta-239651), whereas the youngest date obtained for Unit D at Trench BT36 postdates $750 \pm 40$ years B.P. (Beta-239652). Between 270 and 290 $\mathrm{cm}$ bgs, the dates obtained are in reverse order, complicating the interpretation of when the depositional history of Unit $D$ ended. No evidence of erosional reworking was recorded in the field by Frederick (2008), but the difference between these two dates is statistically insignificant; they may be assumed identical. The depositional history of Unit D undoubtedly terminated before $430 \pm 40$ years B.P., which is a radiocarbon age obtained from cultural material buried at the base of Unit E at 41PT245 (Frederick, 2008).

Based on the geochronology of Unit D, three sedimentation rates were obtained that, along with the biological assemblages described below (Section 4.2), permit the identification of three paleoenvironmental phases during the unit's history: (1) the Early Marsh Phase (1890 \pm 40 years B.P. to $c a .1525$ years B.P.; date estimated from the sedimentation rate calculated for this phase), (2) the Intermediate Marsh Phase ( $c a .1525$ years B.P. to $750 \pm$ 40 years B.P.), and (3) the Late Marsh Phase (post $-750 \pm$
40 years B.P.). These rates indicate a gradual decrease in sediment accumulation from $0.32 \mathrm{~cm} \mathrm{yr}^{-1}$ during the Early Marsh Phase to $0.07 \mathrm{~cm} \mathrm{yr}^{-1}$ during the Intermediate Marsh Phase, and then an increase to $0.33 \mathrm{~cm} \mathrm{yr}^{-1}$ during the Late Marsh Phase (Appendix 1). (Throughout the rest of the paper, I use "phase," "stage," and "interval" interchangeably to refer in general to these three periods.)

Figure 3 shows the composite chronostratigraphy of Unit D according to Frederick (2008). In his study, Frederick established five stratigraphic horizons, occasionally interrupted by thin marly beds. Horizon I, thicker than 60 $\mathrm{cm}$, consists of dark gray to light gray clay with gravel and sand intervals. Horizon II, approximately $124 \mathrm{~cm}$ thick, consists of gray sand with gravel lenses. Horizon III, approximately $71 \mathrm{~cm}$ thick, consists of black clay. Horizon IV, approximately $50 \mathrm{~cm}$ thick, consists of marly black clay. Horizon V, more than $20 \mathrm{~cm}$ thick, consists of black clay (personal interpretation based on Frederick, 2008). In this paper, however, I depart from Frederick's interpretation because of the solid biogeochronological phases noted above and shown in all figures. They are the basis for the paleoclimatic reconstruction of the Upper West Amarillo Creek Valley.

\subsection{The biological record}

Appendix 2 summarizes the biological contents of Unit $\mathrm{D}$ and the overall taphonomic characteristics recorded. Ostracodes, mollusks, and calcareous algae were present. Appendix 3 shows the ecological characteristics of the mollusk species present in the Upper West Amarillo Creek Valley. Appendix 4 shows the total abundance of mollusks by sample and the total and relative abundances of individual species per sample. Adulthood ratios by species are also listed to establish the biocenosis. Appendix 5 lists the ostracode species recorded at Unit D, including their ecological requirements. Appendix 6 summarizes the total abundance of ostracodes by sample and the total and relative abundances by species per sample. Adulthood and disarticulation ratios are included to assist in determining autochthony versus allochthony of the specimens. The record of calcareous algae is documented in Appendices 7 and 8 . Appendix 7 shows the ecological requirements of the species identified, and Appendix 8 presents the total and relative abundances of the species per sample.

The data are plotted in Figures 4-10 to illustrate the biological response to sedimentary and environmental change over time. Figure 4 shows the sand fraction (Figure 4a) and dry-mass abundance (organisms per gram of sediment) of each of the three groups studied (Figure $4 b-d$ ). The biological pattern identified in the sedimentary column permitted the definition of the three marsh phases noted in Section 4.1, and is discussed in the rest of this paper. The biological record is compared to the sand fraction (Figure 4a) to support the suggested zonation of Unit D. 


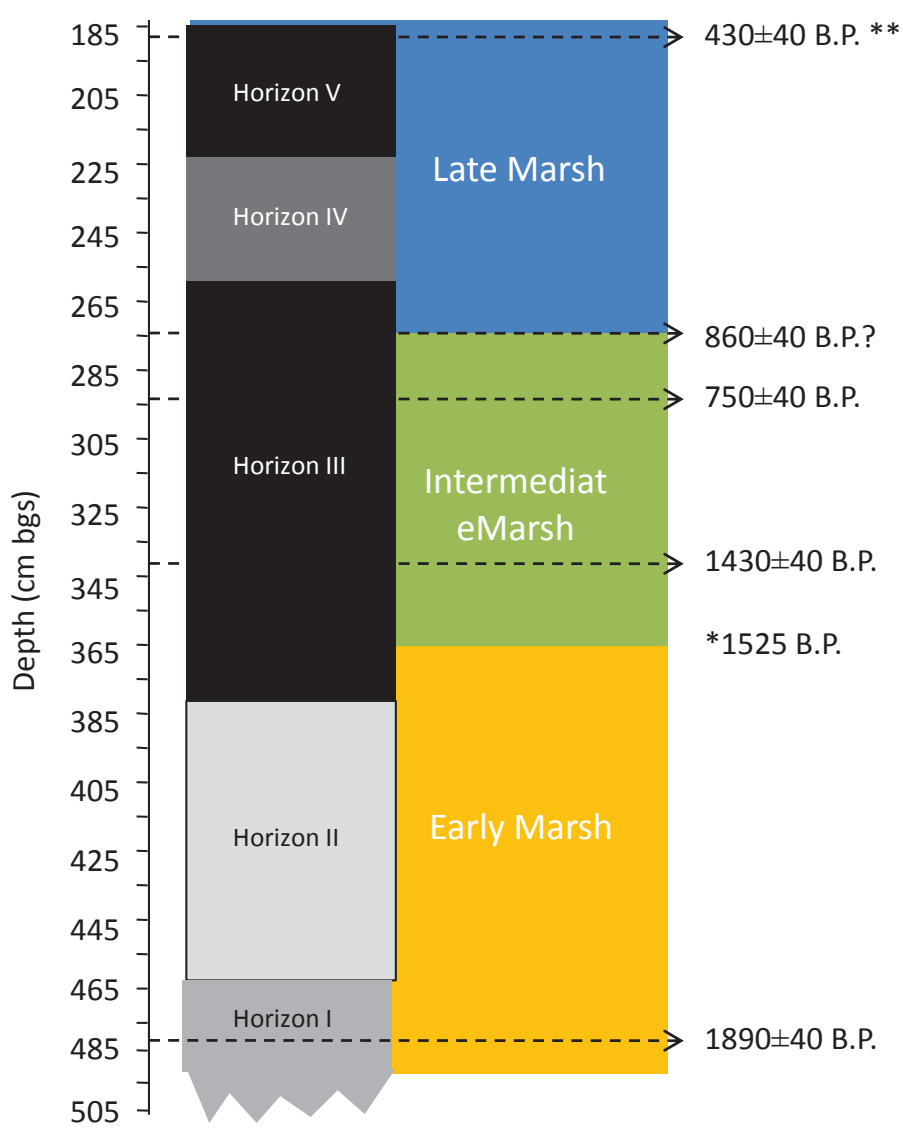

\author{
Date estimated from the $0.32 \mathrm{~cm} \mathrm{yr}^{-1}$ calculated for the Lower \\ Marsh Phase. \\ ? Age in reverse order. However, as shown in the 2 s calibrated age \\ the overlap with the previous dates makes the difference \\ statistically insignificant. \\ ** Denotes date projected from another locality (41PT245).

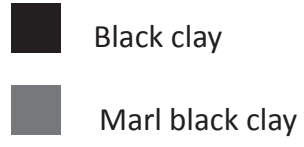 \\ Gray sand \\ Dark gray clay marly
}

Figure 3. Composite chronostratigraphic column for site 41PT185/C, Upper West Amarillo Creek Valley, Texas. The uppermost age (430 \pm 40 years. B.P.) is borrowed from Unit E. The age of $860 \pm 40$ years B.P. is in reverse order with respect to the age below. The two dates overlap; hence they are considered contemporary in this study (Frederick, 2008). Frederick (2008) identified five stratigraphic units. In this study, however, three units are defined by all the data (biological and geochemical), allowing the establishment of the Early, Intermediate, and Late Marsh Phases

\subsubsection{Mollusks}

In the samples from Unit $\mathrm{D}$, mollusks are extremely rare to extremely abundant (2-750 specimens) and diverse (20 species; Figures $4 \mathrm{~b}$ and 5). Abundance categories were defined as follows on the basis of the number of specimens (n): extremely abundant $(>301)$, very abundant $(101<\mathrm{n}$ $<300)$, abundant $(51<\mathrm{n}<100)$, common $(21<\mathrm{n}<50)$, rare $(11<\mathrm{n}<20)$ very rare $(6<\mathrm{n}<10)$, and extremely rare $(<5)$. The species identified are the following: Physella virgata (Gould, 1855), Physella gyrina aurea (Say, 1821), and Stagnicola elodes (Say, 1821), all members of the Physidae; Gyraulus parvus (Say, 1817), Planorbella scalaris (Jay, 1839), Planorbella trivolvis intertexta (Sowerby, 1878), Planorbella trivolvis lenta (Say, 1834), and Menetus brogniartianus (Lea, 1842), all members of the Planorbidae; Fossaria cubensis (Pfeiffer, 1839) and Pseudosuccinea columella (Say, 1817), both members of the Lymnaeidae; Ferrissia hendersoni (Walker, 1908) (Ancylidae); Somatogyrus walkerianus (Aldrich, 1905) (Hydrobiidae); Pisidium sp. (Pfeiffer, 1821) and Musculium transversum (Say, 1829), both members of the Pisidiidae; Pupoides sp. 1, Pupoides sp. 2, Gastrocopta procera (Gould,
1840), Gastrocopta tappaniana (C.B. Adams, 1842), and Columella simplex (Gould, 1840), all members of the Pupillidae; and Polygyra? sp. (Polygyridae) (Appendices 3 and 4$)$.

Figures 5A and 5B show the mollusks records in the Upper West Amarillo Creek Valley. Among the aquatic species, Gyraulus parvus is the dominant species throughout the stratigraphic column, followed by Physella virgata and, to a lesser extent, Somatogyrus walkerianus, Pisidium sp., and Musculium transversum. Other species occur sporadically. Pupoides sp. 1 and Gastrocopta procera are the two most common terrestrial forms co-occurring with the aquatic forms. Other terrestrial gastropods seldom occur in the sedimentary record (Figure 5B).

The paleoenvironmental index generated from this faunal assemblage shows the fluctuations between terrestrial- and aquatic-dominated conditions over time (Figures 5A, 5B, and $8 \mathrm{c}$ ). For example, Figure $5 \mathrm{~A}$ indicates that Unit $\mathrm{D}$ was mostly an aquatic environment. Between $1890 \pm 40$ years B.P. and $c a$. 1525 years B.P., Unit D transformed from a terrestrial to an aquatic system, as indicated by the dominance of Pupoides sp. 1, Gastrocopta procera, and 


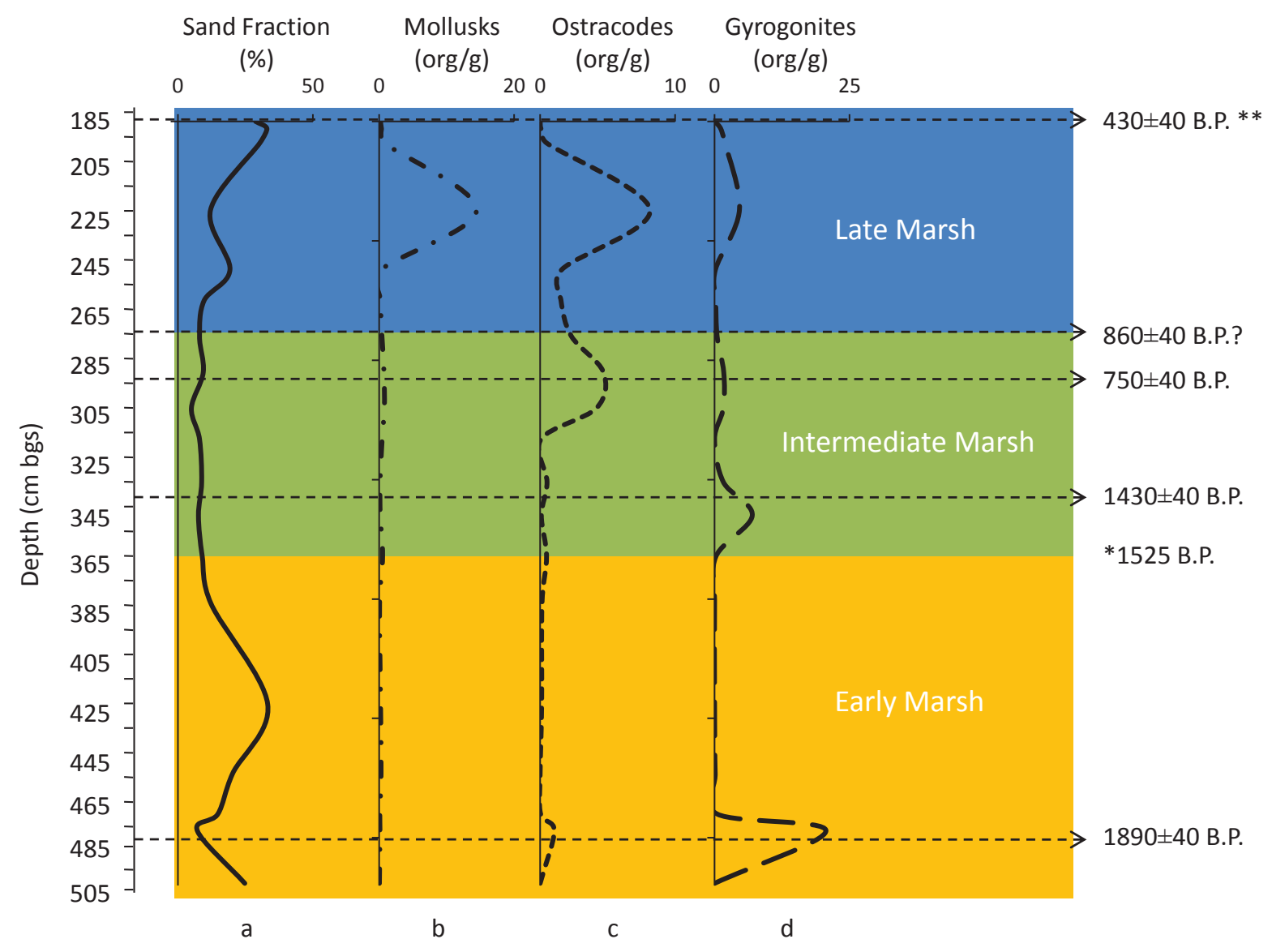

-Date estimated from the $0.32 \mathrm{~cm} \mathrm{yr}^{-1}$ calculated for the Lower Marsh Phase.

-? Age in reverse order. However, as shown in the $2 \mathrm{~s}$ calibrated age the overlap with the previous dates makes the difference statistically insignificant.

** Denotes date projected from another locality (41PT245).

Figure 4. Overall faunal composition showing dry-mass trends over time: (a) sand fraction expressed as weight percent shown to correlate the biological trends with the possible paleohydraulics of the marsh; (b) mollusk dry mass; (c) ostracode dry mass; (d) gyrogonite dry mass. All dry masses are expressed as organisms per gram.

Menetus brogniartianus at the base of the record, replaced by Gyraulus parvus, Ferrissia hendersoni, and Pisidium sp. toward the end of the Early Marsh Phase. Fluctuating conditions ranged from terrestrial to lentic to lotic over time.

During the Intermediate Marsh Phase (between $c a$. 1525 years B.P. and $750 \pm 40$ years B.P.), co-occurrence of terrestrial and aquatic forms suggests that the environment was mostly lentic, ranging from stagnant to riparian conditions where some terrestrial forms thrived. Gyraulus parvus is the most common species, alternating with the terrestrial snail Pupoides sp. 1. However, occurrence of Pisidium sp. and Ferrissia hendersoni in some parts of the record indicates that the environment was lotic at times. Fluctuations between lotic and lentic conditions may have resulted from changes in groundwater level, increasing effective precipitation, or, more likely, a combination of both, suggesting mesic conditions. The Intermediate Marsh Phase, like the Early Marsh Phase, shows a stronger terrestrial signature due to the presence of Gastrocopta procera, Gastrocopta tappaniana, Pupoides sp. 1, Columella simplex, and Menetus brogniartianus (Figure 5B).

The Late Marsh Phase (post $-750 \pm 40$ years B.P.) is characterized by the common occurrence of Pisidium sp. and Musculium transversum in an environment dominated by Gyraulus parvus and Physella virgata. Mollusks reach their greatest concentration during this phase (Figure $4 b$ ). Increasing lotic conditions prevailed in the marsh at this time. Some terrestrial species, however, occur during this phase, indicating the proximity of terrestrial environments to the sampling location. The Late Marsh Phase shows a strong aquatic signature (Figure 5A), suggesting an increase in water discharge into the marsh, which generated a lotic environment (Figures $4 \mathrm{~b}$ and $8 \mathrm{~b}-\mathrm{c}$ ). However, the overall record for the Late Marsh Phase is not as diverse and abundant as those for the Early and Intermediate Marsh Phases, suggesting increasingly xeric conditions. 


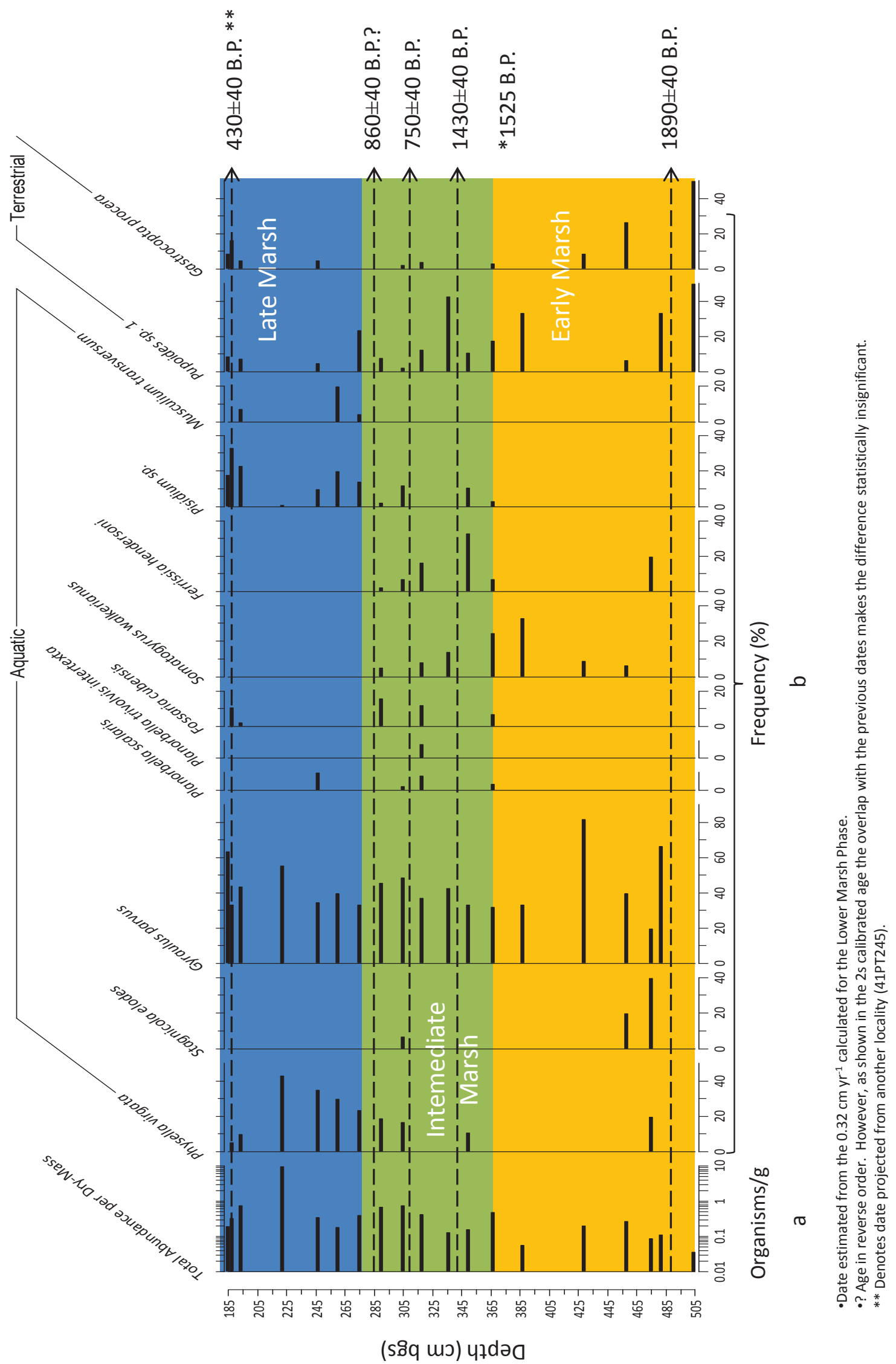

Figure 5A. Micromollusk paleoecology obtained from 19 M-batch sediment samples: (a) dry mass; (b) relative abundance (expressed as percentage). 


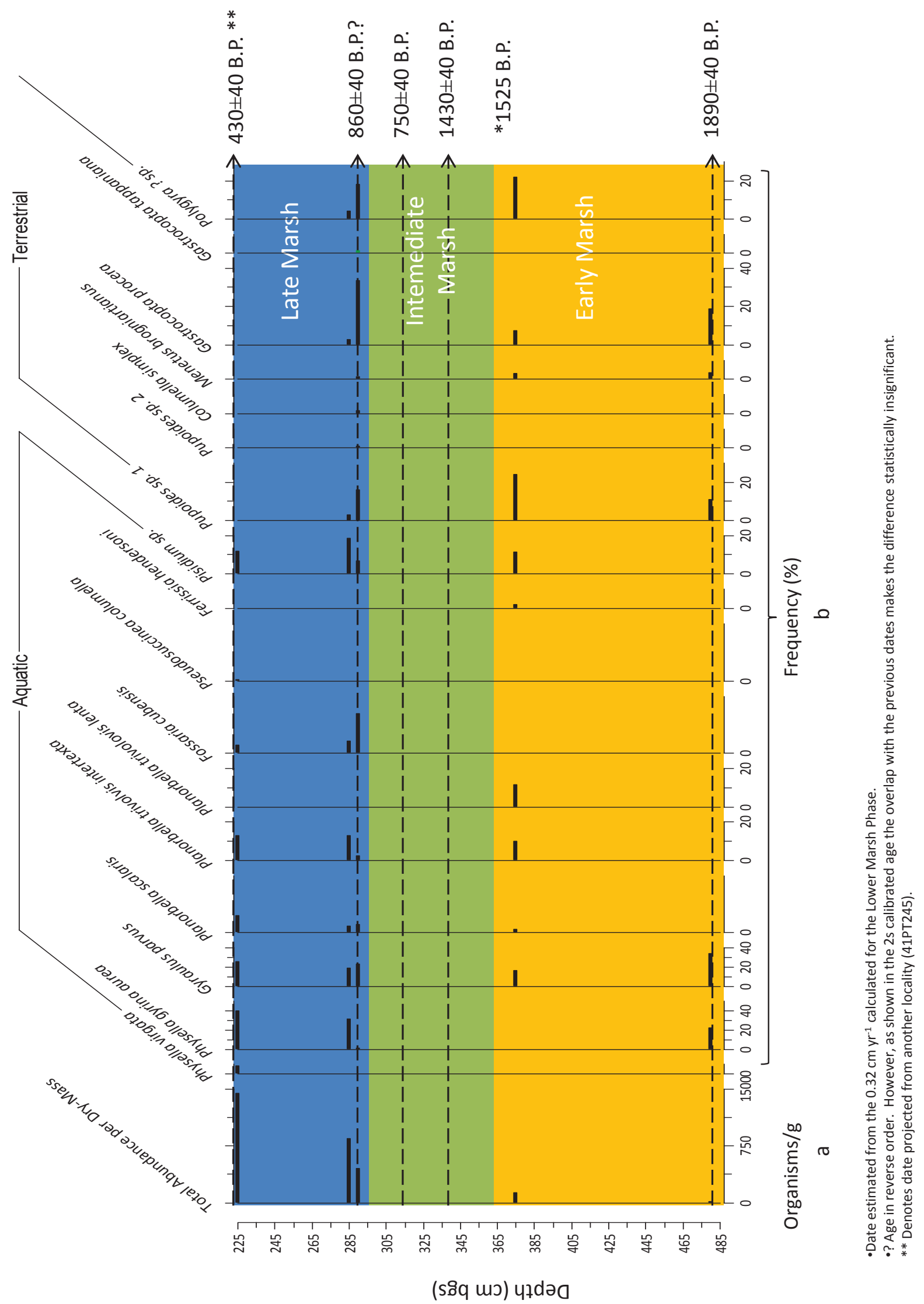

Figure 5B. Micromollusk paleoecology obtained from 5 M-batch sediment samples: (a) dry mass; (b) relative abundance (expressed as percentage). 


\subsubsection{Ostracodes}

In the samples from Unit D, ostracodes are extremely rare to extremely abundant (2-422 specimens) and diverse (15 species), as observed in Figure 4c and Appendix 6. The species identified are Physocypria globula Furtos, 1933; Candona patzcuaro Tressler, 1954; Fabaeformiscandona caudata Kaufmann, 1900; Cypridopsis vidua O.F. Müller, 1776; Ilyocypris bradyi G.O. Sars, 1890; Herpetocypris brevicaudata Kaufmann, 1900; Potamocypris smaragdina Vávra, 1891; Pseudocandona stagnalis G.O. Sars, 1890; Darwinula stevensoni Brady and Robinson, 1870; Eucypris meadensis Gutentag and Benson, 1962; Limnocythere floridensis Keyser, 1976; Physocypria pustulosa Sharpe, 1897; Cypria ophthalmica Jurine, 1820; Cavernocypris wardi? Marmonier, Meisch, and Danielopol, 1989; and Cypridopsis okeechobei Furtos, 1936 (Appendices 5 and 6). Herpetocypris brevicaudata, like Eucypris meadensis, Cypridopsis okeechobei, and Cypridopsis vidua, is a crenophilous species (thriving in springs).

Figure 6 shows the ostracode records for the Upper West Amarillo Creek Valley. Cypridopsis vidua and Physocypria pustulosa are the dominant species over time. Other species occur only intermittently throughout the geologic record. Their occurrence, however, is used to determine environmental trends. Limnocythere floridensis, for example, is a species with stenotopic (restricted) preferences. Forester et al. (2005) reported this species from a few sites in eastern Texas where the total dissolved solids (TDS) range between 200 and $1000 \mathrm{mg} \mathrm{L}^{-1}$ and the carbonate alkalinity/Ca is about $1.00 \mathrm{meq} \mathrm{L}^{-1}$. The species appears at the end of the Early Marsh Phase and thrives through the lower part of the record for the Intermediate Marsh Phase to appear for the last time once in the lower portion of the record for the Late Marsh Phase. Its occurrence is inferred to be associated with dilute water pulses entering the system (mesic conditions).

The candonid Pseudocandona stagnalis occurs at the end of the Intermediate Marsh Phase, to disappear in the earlier part of the Late Marsh Phase. This species is characterized by a wider salinity range than that of Limnocythere floridensis, with which it did not coexist in the record for this study. The sporadic occurrence of other species indicates the limited variability of the environment. That is true for Ilyocypris bradyi, a streamflow indicator occurring at the transition from the Early Marsh Phase to the Intermediate Marsh Phase, suggesting a period of increasing water discharge into the basin. Ilyocypris bradyi is not restricted to flowing waters, but its presence in this interval is consistent with the interpretation of a lotic environment presented in Section 4.2.1.

The salinity index created for this study indicates variations in water chemistry during the deposition of Unit D, associated with a rising water table and increased effective precipitation (Figure 8e). Although the data for mollusks indicate that most of the Early Marsh Phase was aquatic, the ostracode salinity index suggests that predominantly saline waters prevailed over time, with minor fluctuations to more-dilute conditions, except in the upper part of the record, where dilute conditions characterized the end of the phase. Occurrence of Limnocythere floridensis, Cypria ophthalmica, and Darwinula stevensoni with the crenophilous species Eucypris meadensis, Ilyocypris bradyi, Cypridopsis okeechobei, and Cypridopsis vidua toward the end of the phase implies a rising water table and spring discharge. Salinity did not exceed $4000 \mathrm{mg} \mathrm{L}^{-1}$ TDS (the maximum salinity tolerance of Cypridopsis vidua) during the saline periods. It was limited to less than $800 \mathrm{mg} \mathrm{L}^{-1} \mathrm{TDS}$ when Cypridopsis okeechobei thrived in the environment. The mean TDS, however, was in the range of $1000 \mathrm{mg} \mathrm{L}^{-1}$, the optimal salinity for several species to complete their life cycles.

During the Intermediate Marsh Phase, rapid variations in the faunal assemblage, which contains up to nine species throughout the interval, indicate a period of alternating increases and decreases in salinity in response to evapotranspiration during mesic conditions (Figure 8). Salinity ranged around $1000 \mathrm{mg} \mathrm{L}^{-1}$ TDS. Cypridopsis vidua and Physocypria pustulosa continued to dominate the environment. Limnocythere floridensis played a more significant role (as explained earlier in this section) at this time than before or after. Occurrence of Cavernocypris wardi (a spring indicator) at the base of the record for the Intermediate Marsh Phase is in good agreement with the interpretation for the Early Marsh Phase (i.e., dilute water conditions). The species identification, however, is uncertain. Increasing populations around $300 \mathrm{~cm}$ bgs indicate an ecological change that concludes with the accumulation of sediments during the Late Marsh Phase. Frequent occurrence of terrestrial snails during this phase is consistent with this interpretation. The finesediment fraction dominating the system suggests a lentic environment (see detailed discussion in Section 5).

The Late Marsh Phase shows a less variable record, with values indicating increasing salinity as Physocypria globula (a species tolerant of high salinity; Forester et al., 2005) appears at about $245 \mathrm{~cm}$ bgs. The species is limited to that interval, implying that, rather than salinity, it may indicate a spring source as the groundwater table rose. Cypridopsis vidua and Physocypria pustulosa continue to dominate the environment at this time, in association with Physocypria globula, Potamocypris smaragdina, Pseudocandona stagnalis, Darwinula stevensoni, and Cypridopsis okeechobei. Some crenophilous species, like Cypridopsis okeechobei, thrive in the lower portion of the record for this phase; their presence is consistent with a spring source for the marsh. Cypridopsis okeechobei, however, disappears as more saline species enter the system. The occurrence of Potamocypris smaragdina, Pseudocandona stagnalis, and Darwinula stevensoni suggests that salinity exceeded $1000 \mathrm{mg} \mathrm{L}^{-1}$ as Physocypria globula disappeared from the marsh. During this interval, 


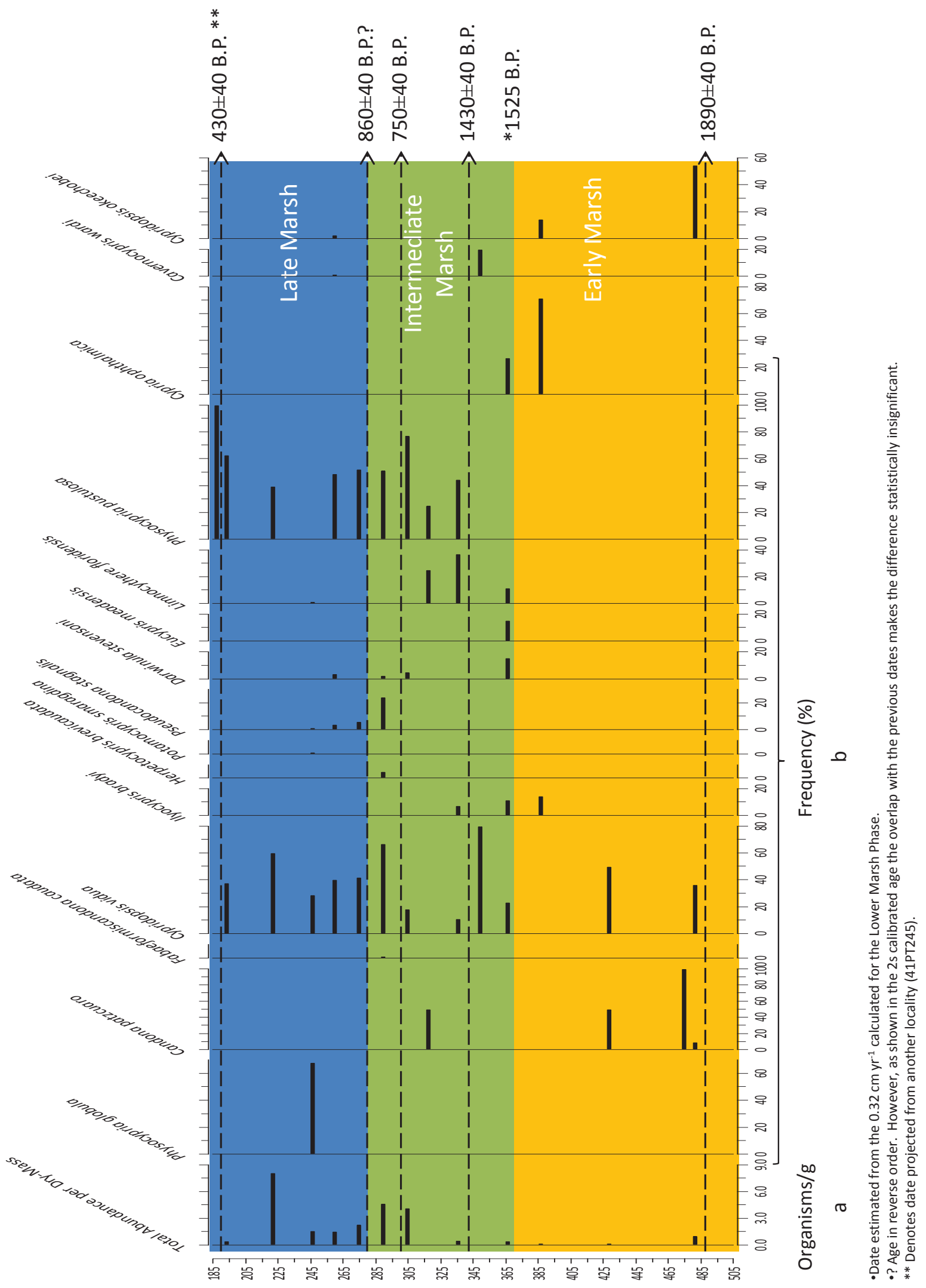

(sรిq uว) чาdə0

Figure 6. Ostracode paleoecology obtained from 19 sediment samples: (a) dry mass; (b) relative abundance (expressed as percentage). 
ostracodes reach their greatest concentration, supporting the hypothesis of a lotic, stable environment as xeric conditions started to dominate (Figures $4 \mathrm{c}$ and $8 \mathrm{~d}-\mathrm{e}$ ).

\subsubsection{Charophyta}

The gyrogonites of charophytes are extremely rare to extremely abundant (2-1081 specimens), as seen in Figure 4d and Appendices 2 and 8). Low diversity (three species, including Chara globularis Thuille, Chara filiformis [Hertsch], and Nitella flexilis [Linnaeus, pro parte]) characterizes the group. Whereas Chara globularis and Chara filiformis prefer high $\mathrm{pH}(>8.5)$, Nitella flexilis thrives in lower $\mathrm{pH}(<8.5)$ (Appendix 7). The gyrogonites of Chara globularis are the most common and abundant in the stratigraphic sequence (Appendix 8). Chara filiformis is scattered throughout the record, whereas Nitella flexilis is limited to the Intermediate and Late Marsh Phases. Based on the species abundance and the alkalinity index developed for the group, Figure $8 \mathrm{~g}$ shows the variations in $\mathrm{pH}$ suggested by the gyrogonites.

At the beginning of the Early Marsh Phase, Chara globularis and Chara filiformis co-occur in the system but then disappear for most of the record in response to increasing aridity. A rising water table introduced both species near the end of the period (Figure 7). The transition from the Early Marsh Phase to the Intermediate Marsh Phase (ca. $1430 \pm 40$ years B.P.) is marked by the appearance of Nitella flexilis, a species that prefers a $\mathrm{pH}$ lower than 8.5 and that dominates the early stages of the Intermediate Marsh Phase. Lower pH may be the result of increasing effective precipitation during more-mesic conditions. Nitella flexilis declines as alkalinity rises to levels more favorable to Chara globularis, which remains the dominant species during the Late Marsh Phase, when more-xeric conditions prevailed. The trend in the alkalinity index shown in Figure $8 \mathrm{~g}$ is consistent with the trend for the paleosalinity index for ostracodes, implying a period of increasing salinity associated with the decline of Nitella flexilis and then a return to moderate salinity, as discussed in Section 4.2.2. As is true for mollusks and ostracodes, gyrogonites reach their greatest concentration during the Late Marsh Phase, supporting the interpretation of a well-oxygenated, lotic, and stable environment (Figures $4 \mathrm{~d}$ and $8 \mathrm{f}-\mathrm{g}$ ).

In addition to the paleoecological signatures of ostracodes, mollusks, and calcareous algae, the stableisotope analyses of ostracodes and gyrogonites provided important information for reconstructing the environment. The geochemical results are discussed in the following section.

\subsection{The stable-isotope data}

A summary of stable-isotope values for Cypridopsis sp. and the gyrogonites are plotted in Figure 8. Figure 9 shows the oxygen and carbon isotopes' moderately positive correlation coefficients for Cypridopsis sp. and gyrogonites.
The Early Marsh Phase is mostly devoid of microfossils, which occur at the base and top of the interval; thus, the discontinuous stable-isotope record provides limited information on environmental change. The Intermediate and Late Marsh Phases, on the other hand, generated valuable data. In Cypridopsis sp., moderately covariant trends in $\delta^{18} \mathrm{O}$ and $\delta^{13} \mathrm{C}$ are evident at the beginning of the Early Marsh Phase and during the Intermediate Marsh Phase, but not during the Late Marsh Phase. A secular isotopic trend toward heavier values in Cypridopsis sp. is discernible for both $\delta^{18} \mathrm{O}$ and $\delta^{13} \mathrm{C}$ values; this signature is weaker in the gyrogonites but still detectable (Figures $8 \mathrm{~h}-\mathrm{k}$ ). These values are consistent with Stable Isotope Stage 1 values recorded for the southern portion of the United States, especially Texas and the eastern states (Wright, 1999).

The single $\delta^{18} \mathrm{O}$ value in Cypridopsis sp. recorded during the Early Marsh Phase limits any interpretation (Appendix 9). During this phase, coarse sediments accumulating in the environment suggest terrestrial influence preventing the settlement of microorganisms. The moderately light $\delta^{18} \mathrm{O}$ value suggests humid conditions during the Early Marsh Phase. The record resumes sometime around 1525 years B.P. (above the base of the record for the Intermediate Marsh Phase). At this time, the values range from -5.93 to $0.59 \%$ in a pattern that goes from lighter to heavier values (Figure $8)$. Then, $\delta^{18} \mathrm{O}$ gradually declines to values lighter than -5 \%o during the Late Marsh Phase. The increase in the $\delta^{18} \mathrm{O}$ values toward the heavier end during the Intermediate Marsh Phase suggests that the area was subjected to increasing aridity during a warm period equivalent to the Medieval Climatic Anomaly (MCA). The steady decline of the $\delta^{18} \mathrm{O}$ values during the Late Marsh Phase indicates gradual cooling and wetter conditions at the onset of the Little Ice Age (Figure 8i).

The $\delta^{13} \mathrm{C}$ values in Cypridopsis sp. (a nektic species that crawls on plants) are interpreted in terms of dissolved inorganic carbon (DIC) and alkalinity/salinity. Values of $\delta^{13} \mathrm{C}$ in closed basins (as Unit D is inferred to have been, at least during part of its environmental history) are less influenced by primary productivity than are those in open lakes (Stiller and Hutchinson, 1980). The only value of $\delta^{13} \mathrm{C}$ recorded during the Early Marsh Phase offers a limited interpretation (Appendix 9). As was true for the $\delta^{18} \mathrm{O}$ values, the coarse sediments suggest more terrestrial influence on the basin. A rising water table permitted the aquatic fauna and flora to thrive again in the system. At the beginning of the Intermediate Marsh Phase (ca. 1525 years B.P.), $\delta^{13} \mathrm{C}$ values average around $-3.7 \%$. During the Intermediate Marsh Phase, $\delta^{13} \mathrm{C}$ values range between -3.5 and -2.3\%o. As the marsh evolved into the Late Marsh Phase, these values turned heavier (from -1.33 to $4.1 \%$ ) and then returned to lighter values toward the end of the record ( -2 to $-3.0 \%$ ).

$\delta^{18} \mathrm{O}$ and $\delta^{13} \mathrm{C}$ values are somewhat covariant during the Intermediate Marsh Phase and the beginning of the Late Marsh Phase, suggesting a closed, shallow basin (Talbot, 1990; $\mathrm{Li}$ and $\mathrm{Ku}, 1997)$, as would be expected during the 


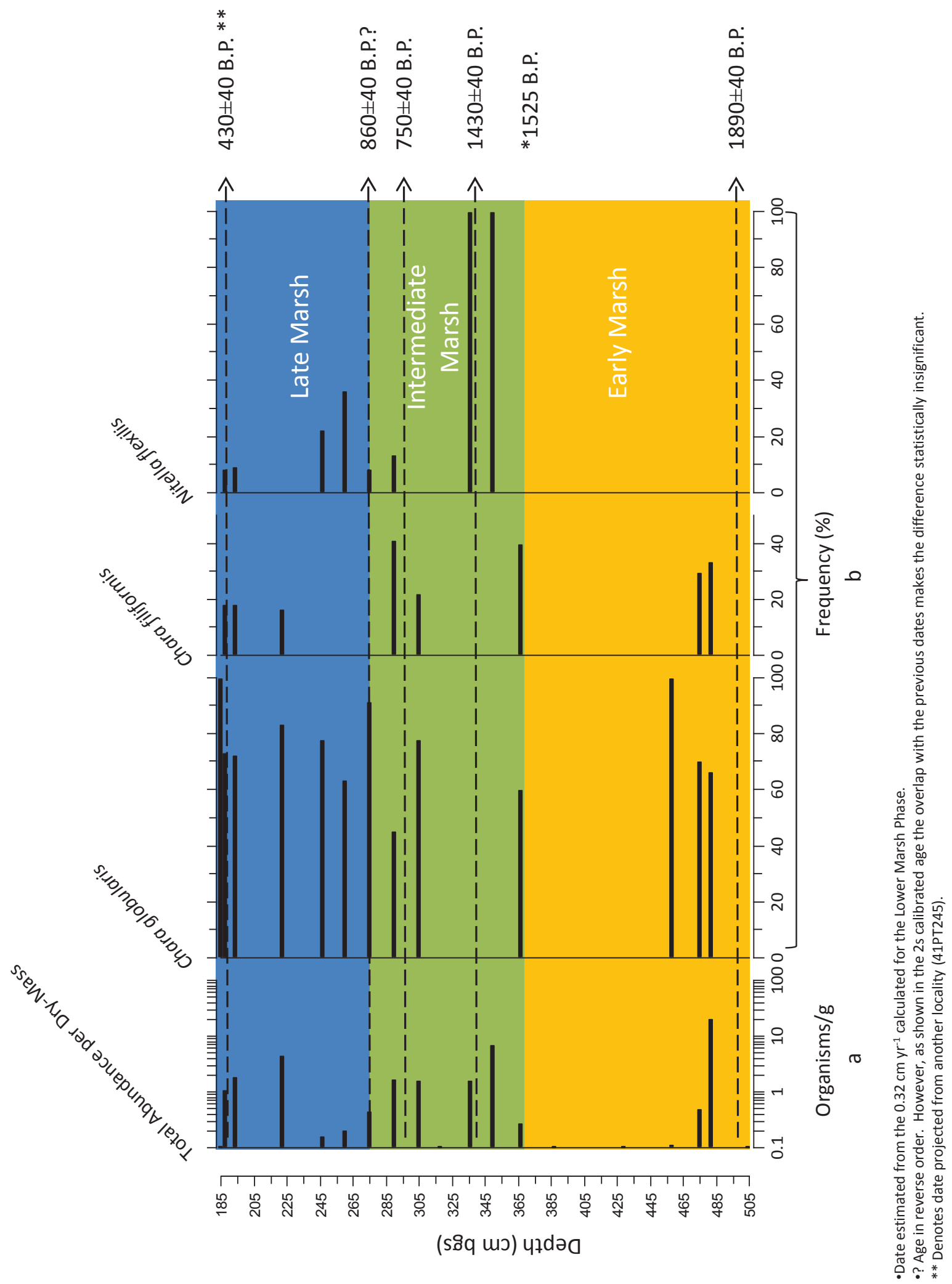

Figure 7. Charophyte paleoecology obtained from 19 sediment samples: (a) dry mass; (b) relative abundance (expressed as percentage). 


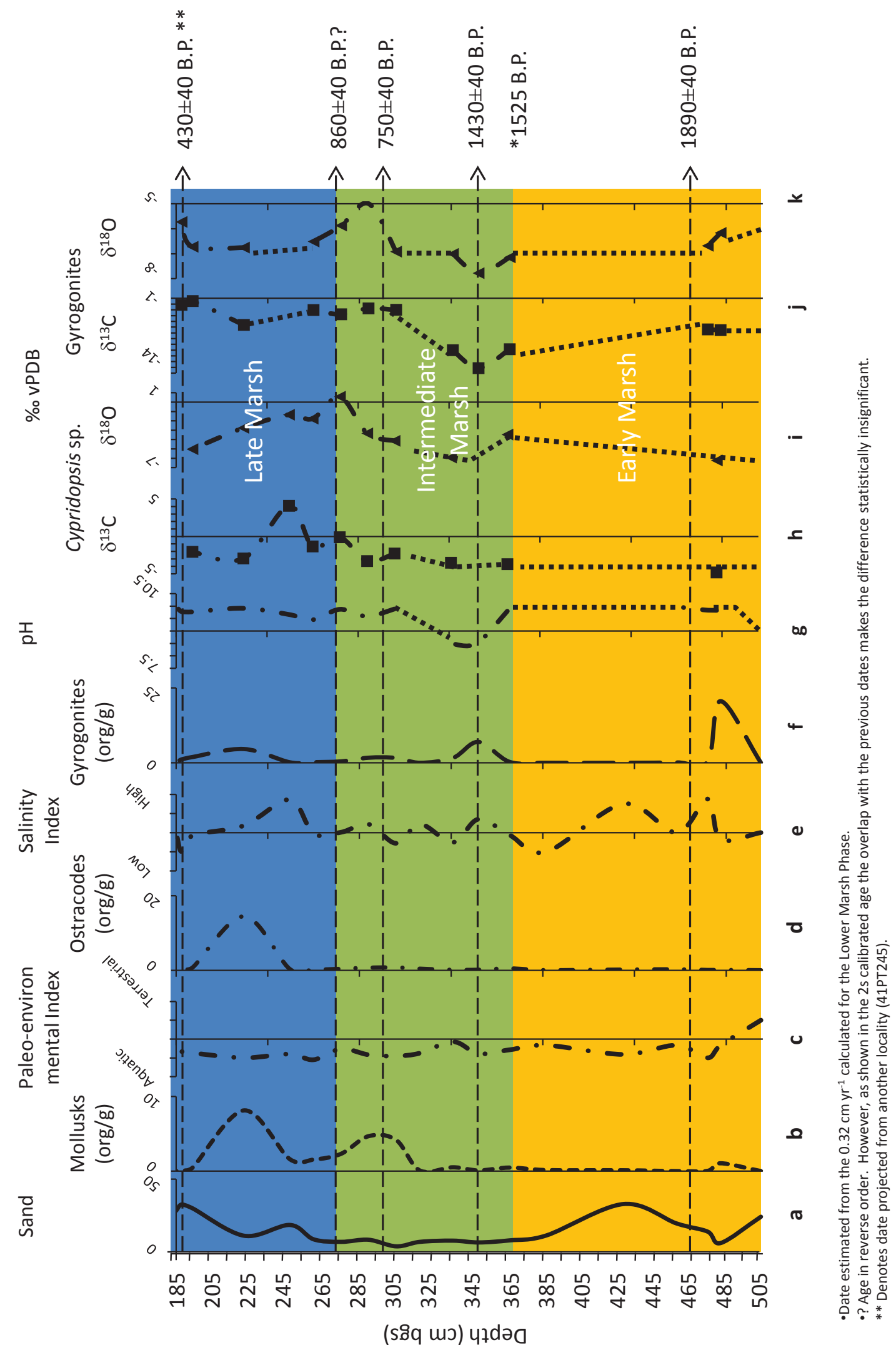

Figure 8. Integrated paleoecological reconstruction combining (a) the sand fraction; (b) mollusk dry mass; (c) PI curve; (d) ostracode dry mass; (e) SI curve; (f) gyrogonite dry mass; (g) AI curve; and (h-k) stable-isotope records $\left(\delta^{13} \mathrm{C}\right.$ and $\left.\delta^{18} \mathrm{O}\right)$ for the ostracodes Cypridopsis okeechobei and Cypridopsis vidua and the gyrogonites Chara globularis and Nitella flexilis. 
Cypridopsis sp. $\delta^{13} \mathrm{C} \% \mathrm{ovPDB}$

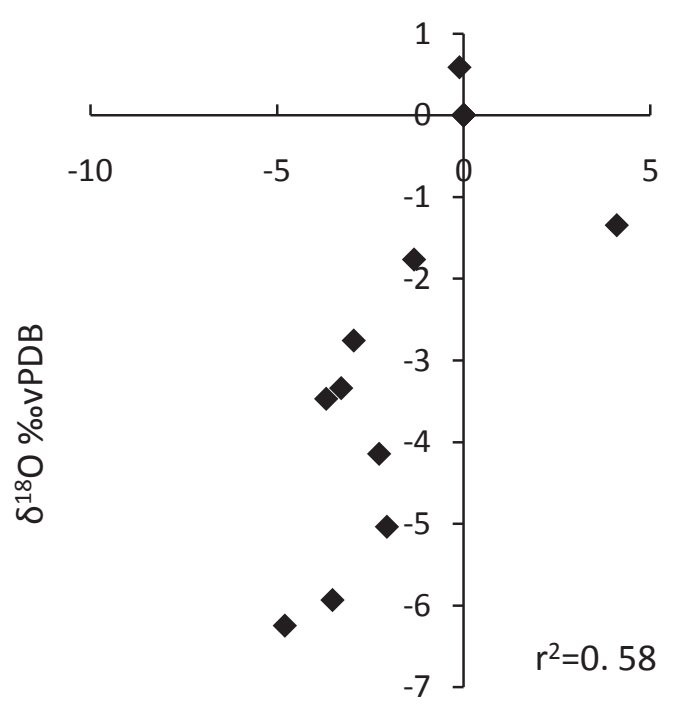

a

\section{Gyrogonites}

$\delta^{13} \mathrm{C} \%$ vPDB

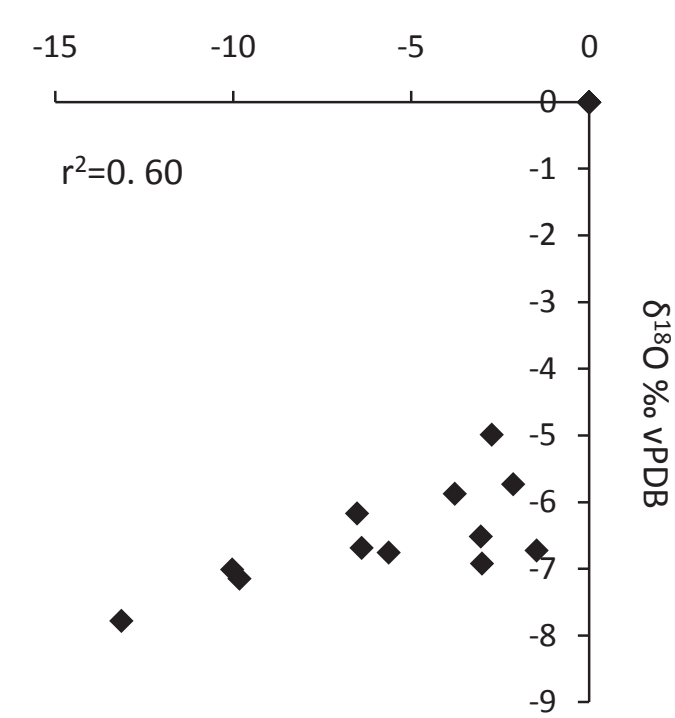

b

Figure 9. Oxygen and carbon isotopes for (a) Cypridopsis sp. and (b) gyrogonites show a moderately positive correlation coefficient for both ostracodes and gyrogonites. This result is consistent with an interpretation of the marsh as a closed basin at site 41PT185/C.

MCA(Figure 8h-i). Figure 9a shows a moderate covariance $\left(r^{2}=0.58\right)$ between $\delta^{18} \mathrm{O}$ and $\delta^{13} \mathrm{C}$ in Cypridopsis sp., supporting the interpretation of closed-basin conditions in the marsh for most of its history (mostly during the MCA). Apparently, at about $250 \mathrm{~cm}$ bgs the marsh reached a point at which the trends for $\delta^{18} \mathrm{O}$ and $\delta^{13} \mathrm{C}$ no longer covary. This breakpoint indicates a transition from a closed to an open basin that is consistent with the hypothesis of a deeper, more open system promoted by the cooling conditions of the Little Ice Age (LIA).

In the gyrogonites, $\delta^{18} \mathrm{O}$ and $\delta^{13} \mathrm{C}$ are moderately covariant $\left(r^{2}=0.60\right.$; figures $8 \mathrm{j}-\mathrm{k}$ and $\left.9 \mathrm{~b}\right)$. The secular isotopic trend for $\delta^{18} \mathrm{O}$ and $\delta^{13} \mathrm{C}$ fluctuates between lighter and heavier values (Appendix 10). As is true for Cypridopsis sp., the $\delta^{18} \mathrm{O}$ values in the lower part of the record for the Early Marsh Phase start light (-6.7\%o) but rapidly disappear because of terrestrial influence and lack of microfossils. At the transition between the Early Marsh Phase and the Intermediate Marsh Phase, $\delta^{18} \mathrm{O}$ values become more negative (greater than $-7.0 \%$ ) once again. Note that this is the interval when isotopic data were obtained from Nitella flexilis because of the absence of Chara globularis. The trend, however, does not seem to disagree with the trend for other variables, like the alkalinity index, derived from the gyrogonite paleoecological data (Figure 8).
The Intermediate Marsh Phase (ca. 1525 years B.P.) shows $\delta^{18} \mathrm{O}$ values that range between $-5 \%$ in Chara globularis and $-7.8 \%$ in Nitella flexilis. Progressively, the lighter values for Nitella flexilis suggest the transition from cooler conditions to warmer, more alkaline environments, whereas the heavier values for Chara globularis imply that, with increasing alkalinity, Nitella flexilis was replaced by this species. The Late Marsh Phase is also an episode when $\delta^{18} \mathrm{O}$ values remain within a limited range (between -5.7 and $-6.8 \%$ ); this relative stability prevents the distinguishing of environmental change. Nevertheless, the values become lighter, consistent with cooling conditions.

At Unit $\mathrm{D}, \delta^{13} \mathrm{C}$ values in gyrogonites range between -1.5 and $-13.5 \%$. During the Early Marsh Phase, $\delta^{13} \mathrm{C}$ values range around $-6.5 \%$ and then rapidly disappear because of the lack of fossils and strong terrestrial influence. As is true for $\delta^{18} \mathrm{O}$ at the transition to the Intermediate Marsh Phase, Nitella flexilis is the gyrogonite present, yielding lighter $\delta^{13} \mathrm{C}$ values (between -9.8 and -13.2\%o). More important, during this interval a strong positive correlation exists between the $\delta^{13} \mathrm{C}$ and alkalinity-index trends, supporting the validity of the data (Figure 8). In contrast to the $\delta^{18} \mathrm{O}$ trend during the Late Marsh Phase, the $\delta^{13} \mathrm{C}$ values show some variability, ranging from -1.5 to $-5.6 \%$.

Pentecost et al. (2006) demonstrated that in well- 
mixed environments, such as shallow streams, the isotopic composition of samples of charophytes is closer to equilibrium than that of samples taken from lentic zones, such as shallow lakes. It is inferred in this study that the Upper West Amarillo Creek Valley marsh was a lotic system in which charophytes calcified gyrogonites near equilibrium. The stable-isotope data, however, cannot be used to obtain reliable air-temperature estimates because modern studies show a strong kinetic disequilibrium throughout the growth period of charophytes resulting from photosynthesis and chemical enhancement of $\mathrm{CO}_{2}$.

\subsection{Interpretation}

The combined paleoecological and geochemical profiles provide a powerful tool for understanding the paleoclimatic history of Unit D. For the first time, a complex record of mollusks, ostracodes, gyrogonites, and stable isotopes $\left(\delta^{13} \mathrm{C}\right.$ and $\delta^{18} \mathrm{O}$ ) are used to identify three paleoenvironmental phases at Unit D in the Upper West Amarillo Creek Valley.

Appendix 11 and Figure 8 summarize the paleoenvironmental history of Unit D using all data available for this study. The three biogeochronological phases recognized in this paper are well defined by the signatures of mollusk, ostracode, and gyrogonite abundances that, in addition, provide associated signatures consistent with the patterns discussed in this section (i.e., the paleoenvironmental index of mollusks, the salinity index of ostracodes, the alkalinity index of gyrogonites, and the stable-isotope records of ostracodes and gyrogonites). In this section I will discuss the environmental history of the Upper West Amarillo Creek Valley by phase, using all the data for each.

\subsubsection{Early Marsh Phase (1890 \pm 40 years B.P. to ca. 1525 years B.P.)}

The transition from terrestrial to aquatic conditions is delineated by the trends in mollusk abundance and diversity. For example, at the base of the record (i.e., at the beginning of the phase), no aquatic mollusks, ostracodes, or gyrogonites were recorded. Soon after the appearance of aquatic microfossils in the stratigraphic column, the transition from terrestrial to aquatic conditions took place during the Early Marsh Phase (Figure 8b-c; Appendix 11). Occurrence of terrestrial gastropods throughout the record demonstrates that the site was exposed to alternating episodes of wetter and drier conditions. The presence of Pisidium sp. and Musculium transversum at some intervals suggests lotic conditions associated with increasing water discharge into the basin, as opposed to episodes of slowly flowing (more lentic) waters that favored the settlement of most of the gastropods identified in this study.

At this time, ostracodes are scarce and scattered. Occurrence of Cypridopsis okeechobei early during deposition of the record for the Early Marsh Phase indicates a freshwater input. The salinity-tolerance range for the species is 50-800 $\mathrm{mg} \mathrm{L}^{-1}$ TDS (Forester et al., 2005). Soon after, Cypridopsis okeechobei disappears and is replaced by Cypridopsis vidua and Candona patzcuaro, two species tolerant of higher salinity (Figure 8d-e; Appendix 5). Toward the end of the phase, ostracode diversity increases (Figure $6)$. The occurrence of environmentally sensitive ostracode species like Limnocythere floridensis, Eucypris meadensis, Cypridopsis okeechobei, and Cypria ophthalmica indicates the paleohydrochemical changes during the Early Marsh Phase. The paleosalinity index derived from ostracode diversity and abundance (Figure 8) suggest that at this time the marsh's salinity ranged between $300 \mathrm{mg} \mathrm{L}^{-1}$ and 2000 $\mathrm{mg} \mathrm{L}^{-1} \mathrm{TDS}$ (primarily around $1000 \mathrm{mg} \mathrm{L}^{-1} \mathrm{TDS}$ ).

The gyrogonites of charophytes provide little information on the possible alkalinity of the Early Marsh Phase (Figure $8 \mathrm{f}-\mathrm{g}$; Appendix 11). Scattered and rare, the gyrogonites of Chara globularis and Chara filiformis are abundant only at the same depth where Cypridopsis okeechobei enters the system. On the basis of our current knowledge of charophyte ecology, the Early Marsh Phase is inferred to have had a high $\mathrm{pH}(>8.5)$ in response to rapid photosynthesis rates in small bodies of water (Becker et al., 2002).

The rare and discontinuous stable-isotope signatures during the Early Marsh Phase limit their value as paleoenvironmental indicators. The younger phases, by contrast, show stronger signatures. The sole fossiliferous sample containing Cypridopsis sp. produced $\delta^{13} \mathrm{C}$ and $\delta^{18} \mathrm{O}$ values that are not useful for an accurate paleoenvironmental reconstruction (Figure 8h-i; Appendix 11). Stable-isotope data for gyrogonites are also limited but concur with the ostracode records (Figure 8j-k; Appendix 11). It is impractical and unwarranted to advance any further interpretation of these data.

\subsubsection{Intermediate Marsh Phase (ca. 1525 years B.P. to $750 \pm 40$ years B.P.)}

During the Intermediate Marsh Phase, abundant terrestrial mollusks coexisting with aquatic forms indicate increasing humidity throughout the interval. The beginning of this phase is marked by data on all three organism groups. For example, Gyraulus parvus dominates the Intermediate Marsh Phase, associated with the aquatic species Somatogyrus walkerianus, Ferrissia hendersoni, Fossaria cubensis, Planorbella trivolvis intertextum, Planorbella scalaris, and Pisidium sp. Alternating with these species are Pupoides sp. 1 and Gastrocopta procera, two terrestrial snails scattered throughout the record (Figure 8b-c; Appendix 4). The paleosalinity-index curve suggests an aquatic system impacted by terrestrial species early in the phase, gradually evolving into a stable aquatic system.

The ostracode record is consistent with the mollusk pattern, as the total dry mass of ostracodes recovered is higher during this period than during the Early Marsh Phase. Populations of ostracode species, though, are not yet as abundant as they will become later during the Late Marsh Phase. Physocypria pustulosa is the dominant species, 
characterized by a salinity-tolerance range of $30-1000 \mathrm{mg} \mathrm{L}^{-1}$ TDS (Forester et al., 2005) (Appendix 5). At the base of the record for (i.e., at the beginning of) the Intermediate Marsh Phase, Cypridopsis vidua is the most abundant ostracode, implying increasing discharge or salinity. As we will see, this signature is contradictory: on the one hand, it agrees with increasing terrestrial influence that may be associated with desiccation; on the other hand, it is not supported by the occurrence of the ostracodes Cavernocypris wardi and Limnocythere floridensis and the gyrogonites of Nitella flexilis, the small charophyte that thrives in low-pH ("soft") water $(7.5<\mathrm{pH}<8.5)$, which may imply dilute water input. Limnocythere floridensis and Cavernocypris wardi are restricted to water salinity no greater than $1000 \mathrm{mg} \mathrm{L}^{-1} \mathrm{TDS}$ (Forester et al., 2005), as observed in Appendix 5. Because the occurrence of Nitella flexilis is restricted to this interval, it is likely that increasing discharge marked the beginning of the Intermediate Marsh Phase. Increasing salinity and alkalinity are indicated by the occurrence of several other ostracodes, such as Pseudocandona stagnalis, Ilyocypris bradyi, Candona patzcuaro, and more rarely Darwinula stevensoni and Herpetocypris brevicaudata (Figure 8d-e).

The gyrogonites of charophytes provide significant information on the possible alkalinity of the Intermediate Marsh Phase. Fluctuating $\mathrm{pH}$ in the system is inferred from the occurrence, and sometimes co-occurrence, of Chara globularis (and Chara filiformis) with Nitella flexilis. Whereas Chara thrives in waters with a high $\mathrm{pH}(>8.5)$ induced by rapid photosynthesis rates in small bodies of water (Becker et al., 2002), Nitellas are found growing in shallow to deep, soft waters or in acid lakes and bogs (Hamel and Parsons, 2001). This study suggests that alternating low to high alkalinity was driven by the reproductive rates of calcareous algae during the late spring to summer months of the year (Figure 8f-g; Appendix 11).

In contrast to the record for the Early Marsh Phase, during the Intermediate Marsh Phase the stable-isotope record is more abundant and continuous (even though this continuity is somewhat limited). The $\delta^{18} \mathrm{O}$ values of Cypridopsis sp. range from -4.14 to $0.59 \%$ from the base to top of (i.e., from early to late) the interval; the $\delta^{13} \mathrm{C}$ values for ostracodes range from -3.68 to $-0.11 \%$ in the same order. Four points may seem insufficient to suggest a trend; however, the $\delta^{13} \mathrm{C}$ and $\delta^{18} \mathrm{O}$ values are covariant (Figure 8h-i; Appendix 11). This pattern is also observed in the stable-isotope signatures of gyrogonites.

Calcareous algae generate stable-isotope values in six of the seven samples in the phase. The $\delta^{18} \mathrm{O}$ values range from -7.78 to $-4.99 \%$ from the base to the top of the sequence. Similarly, the $\delta^{13} \mathrm{C}$ values range from -13.15 to $-2.74 \%$ in the same order. The values are covariant (Figure $8 \mathrm{j}-\mathrm{k}$; Appendix 11). The strong correlation among all the stableisotope data implies that the Intermediate Marsh Phase occurred during the MCA, at which time the marsh was a closed basin.

\subsubsection{Late Marsh Phase (post-750 \pm 40 years B.P.)}

The conclusion of the Intermediate Marsh Phase is marked by a sharp change in the species composition and abundance of mollusks, ostracodes, and calcareous algae associated with sedimentary and isotopic changes. All groups steadily increase in dry mass from the beginning to the middle of the stage. Aquatic mollusks are diverse and abundant throughout most of the record. Gyraulus parvus, Physella virgata, and Pisidium sp. are the dominant species, associated with Musculium transversum and occasionally Fossaria cubensis and Planorbella scalaris. Terrestrial gastropods (Pupoides sp. and Gastrocopta procera) are mostly restricted to the top of the stratigraphic unit (Figure $8 b-c)$.

Ostracodes are diverse and abundant in this interval as well. Physocypria pustulosa continues to dominate the environment, followed by Cypridopsis vidua and, more sporadically, Pseudocandona stagnalis, Darwinula stevensoni, Physocypria globula, Potamocypris smaragdina, Limnocythere floridensis, Cavernocypris wardi, and Cypridopsis okeechobei. The occurrence of Physocypria globula near the base of the record (i.e., early in the phase) indicates saline water, from 10 to $10000 \mathrm{mg} \mathrm{L}^{-1} \mathrm{TDS}$ (Forester et al., 2005). However, its eurytopic characteristics (indicating a wide ecological range) suggest that the marsh held dilute water at this time. This inference is strengthened by its co-occurrence with Limnocythere floridensis, Cavernocypris wardi, and Cypridopsis okeechobei, three species that are stenotopic (i.e., having a restricted ecological range) with a salinity tolerance at or below 1000 $\mathrm{mg} \mathrm{L}^{-1}$ TDS (Forester et al., 2005), as seen in Figure 8d-e and Appendix 5.

Gyrogonites are represented by the three species: Chara globularis, Chara filiformis, and Nitella flexilis. The abundance of Nitella flexilis at the base of the record for the phase indicates that dilute water of low alkalinity entered the aquatic system early. This interpretation is consistent with the ostracode record. Gradually, Chara globularis and, to a lesser extent, Chara filiformis dominate the interval, indicating increasing salinity and alkalinity (Figure $8 \mathrm{f}-\mathrm{g}$ ). As the values for these variables increase, mollusks, ostracodes, and calcareous algae decline; then ostracodes disappear.

The stable-isotope signature indicates that the apparent covariance recorded in the Intermediate Marsh Phase is less evident for Cypridopsis sp. than for the calcareous algae. For example, the $\delta^{18} \mathrm{O}$ for ostracodes changes from a heavy $(-1.77 \%)$ to a light value $(-5.04 \%)$ from the beginning to the end of the record. The $\delta^{13} \mathrm{C}$ values range from $-1.33 \%$ to $4.10 \%$ throughout the interval. The trend indicates the end of covariance between the stable isotopes for ostracodes. In contrast, the $\delta^{18} \mathrm{O}$ values for gyrogonites remain relatively constant throughout the record (around -6.52 to -6.75 $\%$ ), whereas the $\delta^{13} \mathrm{C}$ values fluctuate between -5.63 and $-1.48 \%$. This pattern is erratic, compared to that of other signatures. Again, the limited data available constrain an 
accurate interpretation. However, all the data combined indicate that the Late Marsh Phase occurred during the LIA, as discussed below.

\section{Discussion}

During aquatic stages of a marsh, microinvertebrates and gyrogonites respond to the environment by settling diverse and abundant populations, suggesting stable conditions. The occurrence of environmentally sensitive ostracode species like Limnocythere floridensis, Pseudocandona stagnalis, Cypridopsis okeechobei, and Cypria ophthalmica provides the basic criterion for determining the paleohydrochemical changes in the Upper West Amarillo Creek Valley marsh. The paleosalinity index derived from ostracode abundance and diversity suggests that the marsh's salinity ranged between 300 and $2000 \mathrm{mg} \mathrm{L}^{-1}$ TDS, and was mostly around $1000 \mathrm{mg} \mathrm{L}^{-1}$ TDS (Appendix 5). The occurrence of Physocypria globula (salinity tolerance up to 10000 mg L ${ }^{-1}$ TDS; Forester et al., 2005) suggests that at times salinity rose beyond $2000 \mathrm{mg} \mathrm{L}^{-1} \mathrm{TDS}$, as aridity increased in the area. The introduction of Cypridopsis okeechobei, however, suggests that water salinity dropped below $800 \mathrm{mg}$ $\mathrm{L}^{-1}$ TDS (the maximum tolerance for the species; Forester et al., 2005), to rise and remain around $1000 \mathrm{mg} \mathrm{L}^{-1} \mathrm{TDS}$ during the later part of the Early Marsh Phase and all of the Intermediate Marsh Phase. Rise and fall in salinity characterized the Late Marsh Phase, suggesting increasing aridity followed by wetter conditions, interpreted here as the transition between the MCA and the LIA.

Charophyte fossils have proved valuable in the interpretation of sedimentary records throughout the Quaternary and Tertiary and for parts of the Mesozoic and Paleozoic. Pentecost (1984) found a positive correlation of growth with water temperature in Chara globularis, consistent with the high productivity of gyrogonites recorded in this study. The relatively stable $\delta^{18} \mathrm{O}$ trend over time suggests that the gyrogonites were produced mostly during the optimal growth season (late April to early July). Eutrophication and lake shallowing may have resulted from periods of high productivity, as indicated by charophyte abundance and the alkalinity index. Based on the Eugster and Hardie (1978) model, discussed in Section 3 (Materials and Methods), the aquatic microinvertebrate and algal assemblages indicate that water chemistry alternated between Type $\mathrm{I}\left(\mathrm{Ca}^{2+}, \mathrm{Mg}^{2+}, \mathrm{HCO}_{3}^{-}\right.$in equilibrium $)$and Type III $\left(\mathrm{Ca}^{2+}\right.$-depleted/ $\mathrm{HCO}_{3}{ }^{-}$-enriched).

The stable-isotope signatures contributed to the paleoecological records in establishing that the marsh was a closed basin during most of the period examined in this study, as the $\delta^{13} \mathrm{C}$ and $\delta^{18} \mathrm{O}$ values of both Cypridopsis sp. and the gyrogonites covaried throughout that period. The covariance ceased, however, toward the end of the Late Marsh Phase. The change in the isotopic values over time is quite large $\left(\delta^{18} \mathrm{O}=6.8 \%\right.$ and $\delta^{13} \mathrm{C}=8.9 \%$ in Cypridopsis, and $\delta^{18} \mathrm{O}=2.8 \%$ and $\delta^{13} \mathrm{C}=11.7 \%$ in gyrogonites), indicating substantial climatic changes. The variations in isotopic values are interpreted as resulting primarily from changes in moisture conditions, affecting the abundance of drought-adapted plant species with Crassulacean acid metabolism or CAM (enriched in ${ }^{13} \mathrm{C}$ ). At the Aubrey site in the Trinity River basin in northeastern Texas, Humphrey and Ferring (1994) found a 14000-year stable-isotope record showing that, for the period between 2000 and 1000 years B.P., conditions were drier than they are today. The stableisotope record obtained in this study agrees with that of Humphrey and Ferring (1994).

A correlation between the stable-isotope trends presented in this study and those previously obtained from soil organic carbon (Frederick, 2008) is evident for stratigraphic Unit D (Figure 10). The main difference is that most of the record for the Early Marsh Phase indicates an arid terrestrial environment deprived of aquatic forms, consistent with the poor microfossil record throughout most of this unit; thus, no direct correlation between the stableisotope data in this study and the data for soil organic carbon (SOC) is possible. The trend, however, suggests that as the proportion of $\mathrm{C}_{4}$ plants decreases, the $\delta^{13} \mathrm{C}$ values in $\mathrm{SOC}$, in the gyrogonites, and possibly in Cypridopsis sp. become more negative, implying increasingly mesic conditions. By contrast, an increasing proportion of $\mathrm{C}_{4}$ plants in the area is associated with heavier $\delta^{13} \mathrm{C}$ in SOC and gyrogonites and, to some extent, in Cypridopsis sp. During the Intermediate Marsh Phase, the $\delta^{13} \mathrm{C}$ of gyrogonites and of SOC shows increasingly heavier values, whereas the $\delta^{13} \mathrm{C}$ of Cypridopsis $\mathrm{sp}$. is variable. During the Late Marsh Phase, however, the correlation is weak between the stable-isotope data for SOC and those from this study.

\section{Conclusions}

In summary, this study suggests that the Upper West Amarillo Creek Valley marsh at Unit D remained a year-round aquatic system throughout most of its paleoenvironmental history. The marsh recorded, at least in part, the MCA and the transition into the LIA. This record is consistent with those of other studies across the nation (Petersen, 1987; Stine, 1990; Jones et al., 1999). The record is truncated by the deposition of Unit $\mathrm{E}$, preceded by arroyo-cutting at or after 800 years B.P. The paleoecological signatures used for this study contributed diverse elements for the reconstruction of the marsh's paleoenviromental history. Radiocarbon dates younger than $750 \pm 40$ years B.P. are needed to close the geochronological gap at the end of the record. A better understanding of the stableisotope signatures, especially of gyrogonites, will permit a more precise interpretation of environmental change. This understanding will require the study of modern calcareous algae analogs in the vicinity of the Upper West Amarillo Creek Valley. 


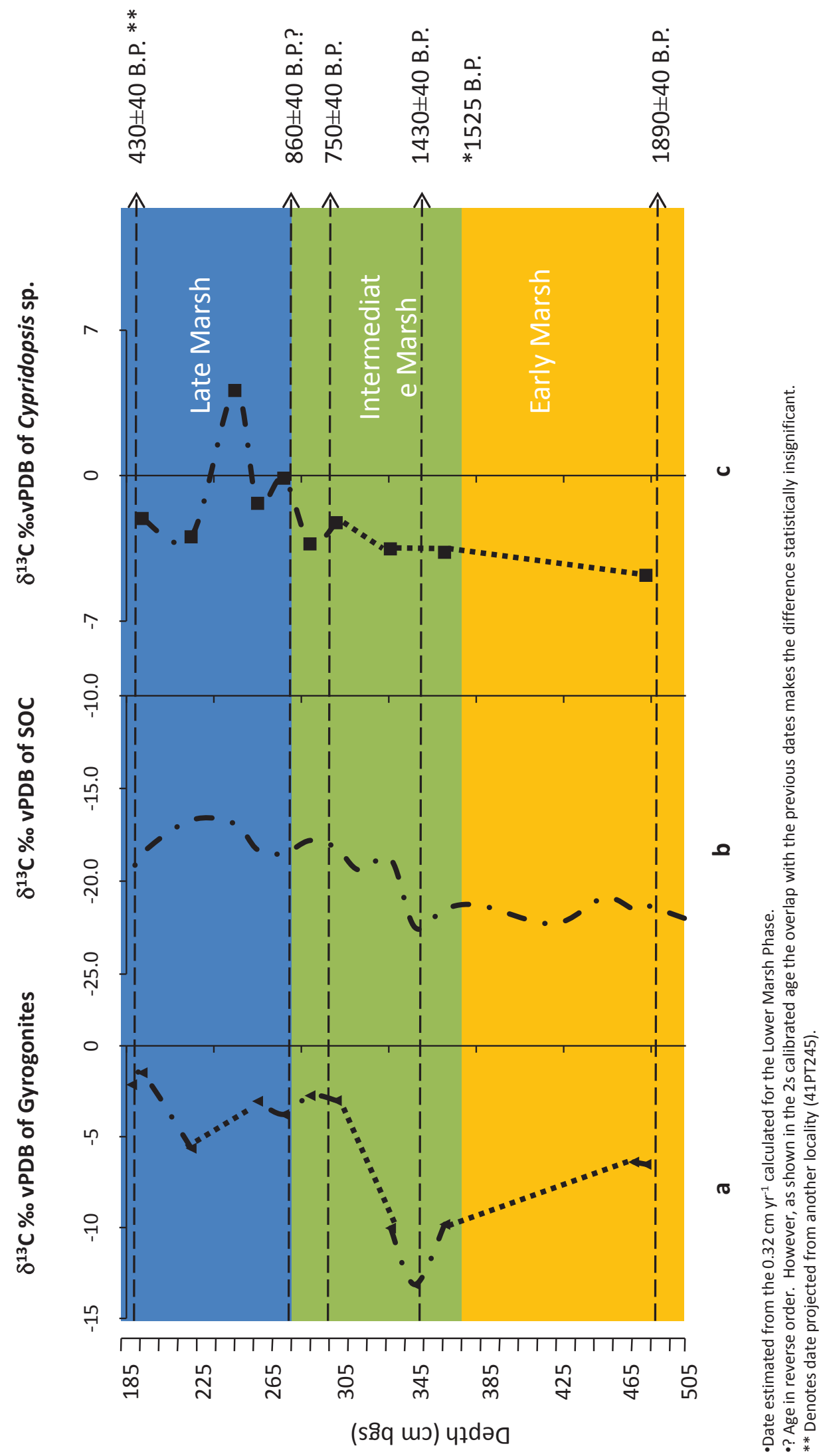

Figure 10. Comparative diagrams of $\delta^{13} \mathrm{C}$ VPDB (\%) obtained from (a) gyrogonites, (b) soil organic carbon (SOC), and (c) Cypridopsis sp. Notice the positive correlation among the three signatures supporting the hypothesis of the transition between the MCA and LIA. 
From an archaeological standpoint, the findings of this study document some of the environmental conditions during the period from $c a .2000$ to $c a .450$ B.P. on the Southern High Plains. Understanding the environment - when it was wet or dry and what type of water was available - is critical to understanding how the prehistoric populations present during those times adapted and adjusted to the natural conditions and changes that occurred. If permanent water was available throughout this period of nearly 1600 years, prehistoric populations would have been aware of this permanent source and would have scheduled their seasonal movements around that knowledge.

Understanding the specific types and conditions of the water in this small valley provides a broader picture of the local and regional paleoclimate. The identification of changes during this period should encourage archaeologists to examine the archaeological record to see if and/or how prehistoric populations may have adapted to those changes. The physical environment represented by Unit D hosted human occupation for a period no longer than 1000 radiocarbon years ( $c a .1550$ and 2550 B.P.).

The paleontological signatures of ostracodes, mollusks, and calcareous algae, as well as the stable-isotope data, do not show evidence of anthropogenic impact. As more archaeological research is conducted in the region, this knowledge of the paleoenvironment will provide a backdrop to examine the archaeological record for changes that might have been the result of past climate changes or conditions.

\section{Acknowledgements}

This study was conducted under subcontract to TRC Solutions, Inc., San Antonio Branch. I am deeply grateful to the company for granting me permission to use the location map and stratigraphic records shown in Figures 1 and 2 of this paper. I particularly thank Michael Quigg and Dr. Charles Frederick for reviewing this paper and for supporting and encouraging me in publishing it. Dr. David L. Dettman was instrumental in conducting the stable-isotope analysis and providing key suggestions for interpreting the data. Last but not least, the unidentified reviewers' comments and suggestions were invaluable in improving the quality and clarity of this complex investigation.

\section{References}

Adams, K.R., Smith, S.J., Palacios-Fest, M.R., 2002, Pollen and micro-invertebrates from modern earthen canals and other fluvial environments along the Middle Gila River, Central Arizona: Implications for archaeological interpretation: Tucson, Arizona, U.S.A., University of Arizona Press, 76 p.

Allen, G.O., 1950, British Stoneworts (Charophyta): Arbroath, Great Britain, Haslemere Natural History Society-T. Buncle and Co., 52 p.

Anderson, D.H., Darring, S., Benke, A.C., 1998, Growth of crustacean meiofauna in a forested floodplain swamp: implications for biomass turnover: Journal of the North American Benthological Society,
17, 21-36.

Andrews, J.E., Coletta, P., Pentecost, A., Riding, R., Dennis, S., Dennis, P.F., Spiro, B., 2004, Equilibrium and disequilibrium stable isotope effects in modern charophyte calcites: implications for palaeoenvironmental studies: Palaeogeography, Palaeoclimatology, Palaeoecology, 204, 101-114.

Becker, D., Picot, L., Berger, J.P., 2002, Stable isotopes $\left(\delta^{13} \mathrm{C}\right.$ and $\left.\delta^{18} \mathrm{O}\right)$ of charophyte gyrogonites: example from the Brochene Fluh section (Late Oligocene-Early Miocene, Switzerland): Geobios, 35, 89-97.

Bequaert, J.C., Miller, W.B., 1973, The mollusks of the Arid Southwest, with an Arizona checklist: Tucson, Arizona, U.S.A., University of Arizona Press, $271 \mathrm{p}$.

Brouwers, E.M., 1988, Sediment transport detected from the analysis of ostracod population structure: an example from the Alaskan Continental Shelf, in de Deckker, P., Colin, J.-P., Peypouquet J.-P. (eds.), Ostracoda in the earth sciences: Amsterdam, The Netherlands, Elsevier, 231-244.

Caran, S.C., 1991, Cenozoic stratigraphy, southern Great Plains area, in Morrison, R.B. (ed.), Quaternary nonglacial geology: conterminous United States: Boulder, Colorado, U.S.A., Geological Society of America, Centennial Volume K-2, Plate 5.

Cohen, A.S., Palacios-Fest, M.R., Negrini, R.M., Wigand, P.E., Erbes, D., 2000, A paleoclimate record for the past 250000 years from Summer Lake, Oregon, USA: II. Sedimentology, paleontology and geochemistry: Journal of Paleolimnology, 24, 151-182.

Coletta, P., Pentecost, A., Spiro, B., 2001, Stable isotopes in charophyte incrustations: relationships with climate and water chemistry: Palaeogeography, Palaeoclimatology, Palaeoecology, 173, 9-19.

Coplen, T.B., 1994, Reporting of stable hydrogen, carbon and oxygen isotopic abundances (Technical Report): Pure and Applied Chemistry, 66, 273-276.

Cotter, J.L., 1937, The occurrence of flints and extinct animals in pluvial deposits near Clovis, New Mexico, Part IV, Report on excavation at the Gravel Pit, 1936: Proceedings of the Academy of Natural Sciences of Philadelphia, 89, 1-16.

Curry, B.B., 1999, An environmental tolerance index for ostracodes as indicators of physical and chemical factors in aquatic habitats: Palaeogeography, Palaeoclimatology, Palaeoecology, 148, 51-63.

de Deckker, P., 1983, The limnological and climatic environment of modern ostracodes in Australia - a basis for paleoenvironmental reconstruction, in Maddocks, R.F. (ed.), Proceedings of the Eighth International Symposium on Ostracoda: Houston, Texas, U.S.A., University of Houston, 250-254.

de Deckker, P., Forester, R.M., 1988, The use of ostracodes to reconstruct paleoenvironmental records, in de Deckker, P., Colin, J.-P., Peypouquet, J.-P. (eds.), Ostracoda in the Earth Sciences: Amsterdam, The Netherlands, Elsevier, 175-199.

Delorme, L.D., 1969, Ostracodes as Quaternary paleoecological indicators: Canadian Journal of Earth Sciences, 6, 1471-1476.

Delorme, L.D., 1978, Distribution of freshwater ostracodes in Lake Erie: Journal of Great Lakes Research, 4, 216-220.

Delorme, L.D., 1989, Methods in Quaternary Ecology Vol. 7: Freshwater Ostracodes: Geoscience Canada, 16, 85-90.

Delorme, L.D., Zoltai, S.C., 1984, Distribution of an arctic ostracode fauna in space and time: Quaternary Research, 21, 65-73.

Dillon, R.T., 2000, The Ecology of Freshwater Molluscs: Cambridge, United Kingdom, Cambridge University Press, 509 p.

Dillon, R.T., Stewart, T.W., 2003, The freshwater gastropods of South Carolina (on line): South Carolina, U.S.A., College of Charleston, updated August 2003, Available at $<$ http://www.fwgna.org/ FWGSC $>$, Accessed November 102009.

Eugster, H.P., Hardie, L.A., 1978, Saline lakes, in Lerman, A. (ed.), Lakes: Chemistry, geology, physics: New York, U.S.A., Springer-Verlag, 237-293.

Eversole, A.G., 1978, Life-cycles, growth and population bioenergetics in the snail Helisoma trivolvis (Say): Journal of Molluscan Studies, 44, 209-222.

Eyles, N., Schwarcz, H.P., 1991, Stable isotope record of the last glacial cycle from lacustrine ostracodes: Geology, 19, 257-260. 
Forester, R.M., 1983, Relationship of two lacustrine ostracode species to solute composition and salinity: Implications for paleohydrochemistry: Geology, 11, 435-438.

Forester, R.M., 1985, Limnocythere bradburyi n. sp.: A Modern Ostracode from Central Mexico and a Possible Quaternary Paleoclimate Indicator: Journal of Paleontology, 59, 8-20.

Forester, R.M., 1986, Determination of the dissolved anion composition of ancient lakes from fossil ostracodes: Geology, 14, 796-799.

Forester, R.M., 1987, Late Quaternary paleoclimate records from lacustrine ostracodes, in Ruddiman, W.F., Wright, H.E., (eds.), North America and adjacent oceans during the last deglaciation: Boulder, Colorado, U.S.A.,Geological Society of America. The geology of North America, v. K-3, 261-276.

Forester, R.M., 1988, Nonmarine calcareous microfossil sample preparation and data acquisition procedures: Washington, D.C., U.S.A., U.S. Geological Survey Technical Procedure, HP-78, R1, 1-9.

Forester, R.M., 1991, Ostracode assemblages from springs in the western United States: implications for paleohydrology: Memoirs of the Entomological Society of Canada, 155, 181-201.

Forester, R.M., Smith, A.J., Palmer, D.F., Curry, B.B., 2005, North American Non-Marine Ostracode Database (NANODe), Version 1 (on line): Kent, Ohio, U.S.A., Kent State University available at $<$ http://www.kent.edu/NANODe, Accessed November 102010.

Frederick, C.D., 2008, Stratigraphic overview of the Upper West Amarillo Creek Valley, in Quigg, J.M., Frederick, C.D., Luedecke, K.G., Final interim report for Phase I of the Data Recovery at Three Prehistoric Sites (41PT185, 41PT186, and 41PT245) Located within the Landis Property in Potter County, Texas: Austin, Texas, U.S.A., TRC Solutions, TRC Project No. 150832, 18-30.

Haecker, C. M., 1999, Phase I Archeological Survey: Amarillo and Exell Helium Plants and Landis Property, Potter and Moore Counties, Texas: Santa Fe, New Mexico, U.S.A., National Park Service, Intermountain Support Office, Anthropology Program, for U.S. Department of the Interior Bureau of Land Management, Helium Operations Unit, Amarillo, Texas.

Hamel, K., Parsons, J., 2001, Plant-like algae, in Hamel, K., Parsons, J. (eds.), An on-line version of An aquatic plant identification manual for Washington's freshwater plants (on line): Olympia, Washington, U.S.A., Washington State Department of Ecology, available at $<$ http://www.ecy.wa.gov/programs/wq/plants/plantid2/descriptions/ nit.html >, Accessed February 3rd 2009.

Holmes, J.A., Chivas, A.R., 2002, Ostracod shell chemistry-overview, in Holmes, J.A., Chivas, A.R. (eds.), The Ostracoda: Applications in Quaternary Research, Geophysical Monograph Series 131: Washington, D.C., American Geophysical Union, 185-204.

Horne, D.J., Cohen, A., Martens, K., 2002, Taxonomy, morphology and biology of Quaternary and living Ostracoda, in Holmes, J.A., Chivas, A.R. (eds.), The Ostracoda: Applications in the Quaternary Research, Geophysical Monograph Series 131: Washington, D.C., American Geophysical Union, 5-36.

Howard, E.B., 1935, Evidence of Early Man in North America: Museum Journal, University of Pennsylvania, 24, 61-175.

Humphrey, J.D., Ferring, C.R., 1994, Stable isotopic evidence for latest Pleistocene and Holocene climatic change in north-central Texas: Quaternary Research, 41, 200-213.

Johnson, E., Holliday, V.T., 2004, Archaeology and late Quaternary environments of the Southern High Plains, in Perttula, T.K. (ed.), Prehistory of Texas: College Station, Texas, U.S.A., Texas A\&M University Press, 283-295.

Jones, T.L., Brown, G.M., Raab, L.M., McVickar, J.L., Spaulding, W.G., Kennett, D.J., York, A., Walker, P.L., 1999, Environmental imperatives reconsidered: demographic crises in Western North America during the Medieval Climatic Anomaly: Current Anthropology, 40, 137-170.

Külköylüoĝlu, O., Vinyard, G.L., 2000, Distribution and ecology of freshwater Ostracoda (Crustacea) collected from springs of Nevada, Idaho, and Oregon: a preliminary study: Western North American
Naturalist, 60, 291-303.

Lewis, C.F.M., Moore, T.C., Rea, D.K., Dettman, D.L., Smith, A.M., Mayer, L.A., 1994, Lakes of the Huron basin: their record of runoff from the laurentide ice sheet: Quaternary Science Reviews, 13, 891-922.

Li, H.-C., Ku, T.-L., 1997, $\delta^{13} \mathrm{C}-\delta^{18} \mathrm{O}$ covariance as a paleohydrological indicator for closed-basin lakes: Palaeogeography, Palaeoclimatology, Palaeoecology, 133, 69-80.

Lister, G.S., 1988, Stable isotopes from lacustrine Ostracoda as tracers for continental paleoenvironments, in de Deckker, P., Colin, J.-P., Peypouquet, J.-P. (eds.), Ostracoda in the Earth Sciences: Amsterdam, The Netherlands, Elsevier, 210-218.

Miksicek, C.H., 1989, Snails, seeds, and charcoal: Macrofossils from Las Acequias Canals, in Ackerly, N.W., Henderson, T.K. (eds.), Prehistoric agricultural activities on the Lehi-Mesa Terrace: perspectives on Hohokam irrigation cycles: Flagstaff, Arizona, U.S.A., Northland Research, 235-261.

Palacios-Fest, M.R., 1994, Nonmarine ostracode shell chemistry from Hohokam irrigation canals in central Arizona: A paleohydrochemical tool for the interpretation of prehistoric human occupation in the North American Southwest: Geoarchaeology, 9, 1-29.

Palacios-Fest, M.R., 2002, Significance of Ostracode Studies in Geoarchaeology: Examples From the United States Southwest: Kiva, 68, 49-66.

Palacios-Fest, M.R., 2008, Younger Dryas Ostracode Paleoecology of Scholle Cienega, Abo Arroyo, New Mexico: Tucson, Arizona, U.S.A., Terra Nostra Earth Sciences Research, TNESR Report 08-10.

Palacios-Fest, M.R., Cohen, A.S., Monzón, P.A., 1994, Use of ostracodes as paleoenvironmental tools in the interpretation of ancient lacustrine records: Revista Española de Micropaleontología, 9, 145-164.

Palacios-Fest, M.R., Mabry, J.B., Nials, F., Holmlund, J.P., Miksa, E., Davis, O.K., 2001, Early irrigation systems in southeastern Arizona: the ostracode perspective: Journal of South American Earth Sciences, $14,541-555$

Pentecost, A., 1984, The growth of Chara globularis and its relationship to calcium carbonate deposition in Malham Tarn: Field Studies, $6,53-58$.

Pentecost, A., Andrews, J.E., Dennis, P.F., Marca-Bell, A., Dennis, S., 2006, Charophyte growth in small temperate water bodies: extreme isotopic disequilibrium and implications for the palaeoecology of shallow marl lakes: Palaeogeography, Palaeoclimatology, Palaeoecology, 240, 389-404.

Petersen, K.L., 1987, Climate and the Dolores River Anasazi: A Paleoenvironmental Reconstruction from a 10000-Year Pollen Record, La Plata Mountains, Southwestern Colorado: Salt Lake City, Utah, U.S.A., University of Utah Anthropological Papers 113, University of Utah Press, $152 \mathrm{p}$.

Pokorný, V., 1978, Ostracodes, in Haq, B.U., Boersma, A. (eds.), Introduction to marine micropaleontology: New York, U.S.A., Elsevier, 109-149.

Quigg, J.M., 2008, Introduction, in Quigg, J.M., Frederick, C.D., Luedecke, K.G. (eds.), Final interim report for Phase I of the data recovery at three prehistoric sites (41PT185, 41PT186, and 41PT245) located within the Landis Property in Potter County, Texas: Austin, Texas, U.S.A., TRC Solutions, TRC Project No. 150832, 1-4.

Quigg, J.M., Frederick, C.D., Luedecke, K.G., 2008, Final Interim Report for Phase I of the Data Recovery at Three Prehistoric Sites (41PT185, 41PT186, and 41PT245) Located within the Landis Property in Potter County, Texas: Austin, Texas, U.S.A., TRC Solutions, TRC Project No. 150832.

Rutherford, J., 2000, Ecology illustrated field guides (on line): Waterloo, Ontario, Canada, Wilfrid Laurier University, revised October 3 2000, Available at < http://www.wlu.ca/science/biology/eschweigert/ bio305/Database/FieldGuide.htm>, Accessed 28 May 2007.

Sellards, E.H., 1952, Early man in America: A study in Prehistory: Austin, Texas, U.S.A., University of Texas Press, 211 p. 
Sharpe, S., 2002, Solute composition: a parameter affecting the distribution of freshwater gastropods (on line), in Sada, D.W., Sharpe, S.E. (eds.) Conference proceedings, Spring-fed wetlands: important scientific and cultural resources of the Intermountaine Region, Las Vegas, Nevada, U.S.A.: Desert Research Institute, Available at $<$ http:// wetlands.dri.edu/2002/papersTOC.html>, Accessed 12 March 2004.

Sovell, J.R., Guralnick, R., 2004, Montane mollusk and crustacean survey of western Colorado (on line), 2003 annual report. A report to the Colorado Division of Wildlife: Fort Collins, Colorado, Colorado State University, Available at < http://www.cnhp.colostate.edu/ download/documents/2004/Montane Mollusk and Crustacean Survey 2004.pdf>, Accessed September 142010.

Stiller, M., Hutchinson, G.E., 1980, The waters of Merom: a study of Lake Huleh, Part 1-Stable isotopic composition of carbonates of a $54 \mathrm{~m}$ core, paleoclimatic and paleotrophic implications: Archiv für Hydrobiologie, 89, 275-302.

Stine, S., 1990, Late holocene fluctuations of Mono Lake, eastern California: Palaeogeography, Palaeoclimatology, Palaeoecology, 78, 333-381.

Talbot, M.R., 1990, A review of the paleohydrological interpretation of carbon and oxygen isotopic ratios in primary lacustrine carbonates: Chemical Geology (Isotope Geoscience Section), 80, 261-279.

United States Department of Agriculture (USDA), 2003, Soil Survey Manual: Honolulu, Hawaii, U.S.A., University Press of the Pacific.

Vokes, A.W., Miksicek, C.H., 1987, Snails, clams, and canals: an analysis of nonmarine molluscan remains, in Masse, W.B. (ed.), Archaeological investigations of portions of the Las Acequias-Los Muertos irrigation system: testing and partial data recovery within the Tempe section of the Outer Loop Freeway System, Maricopa County, Arizona: Tucson, Arizona, U.S.A., Archaeological Series No. 176, Arizona State Museum, 177-187.

von Grafenstein, U., Eicher, U., Erlenkeuser, H., Ruch, P., Schwander, J., Ammann, B., 2000, Isotope signature of the Younger Dryas and two minor oscillations at Gerzensee (Switzerland): palaeoclimatic and palaeolimnologic interpretation based on bulk and biogenic carbonates: Palaeogeography, Palaeoclimatology, Palaeoecology, $159,215-229$.
Webb, W.F., 1942, United States Mollusca-A descriptive manual of many of the marine, land and fresh water shells of North America, north of Mexico: New York, U.S.A., Bookcraft Press, 220 p.

Wendorf, F., 1961, Paleoecology of the Llano Estacado: Santa Fe, New Mexico, U.S.A., Publication of the Fort Burgwin Research Center No. 1, Museum of New Mexico Press, 144 p.

Wendorf, F., Hester, J.J., 1975, Late Pleistocene Environments of the Southern High Plains: Ranchos de Taos, New Mexico, U.S.A., Fort Burgwin Research Center Publication No. 9, 290 p.

Whatley, R., 1983, Some simple procedures for enhancing the use of Ostracoda in palaeoenvironmental analysis: Norwegian Petroleum Directorate Bulletin, 2, 129-146.

Wright, J.D., 1999, Global climate change in marine stable isotope records, in Noller, J.S., Sowers, J., Lettis, W.R. (eds.) Quaternary Geochronology: Applications in Quaternary Geology and Paleoseismology: Washington, D.C., U.S. Nuclear Regulatory Commission, NUREG/CR 5562, 671-682.

Wrozyna, C., Frenzel, P., Steeb, P., Zhu, L., van Geldern, R., Mackensen, A., Schwalb, A., 2010, Stable isotope and ostracode species assemblage evidence for lake level changes of Nam Co, southern Tibet, during the past 600 years: Quaternary International, 212, 2-13

Manuscript received: October 5, 2009.

Corrected manuscript received: June 4, 2010.

Manuscript accepted: July 22, 2010. 


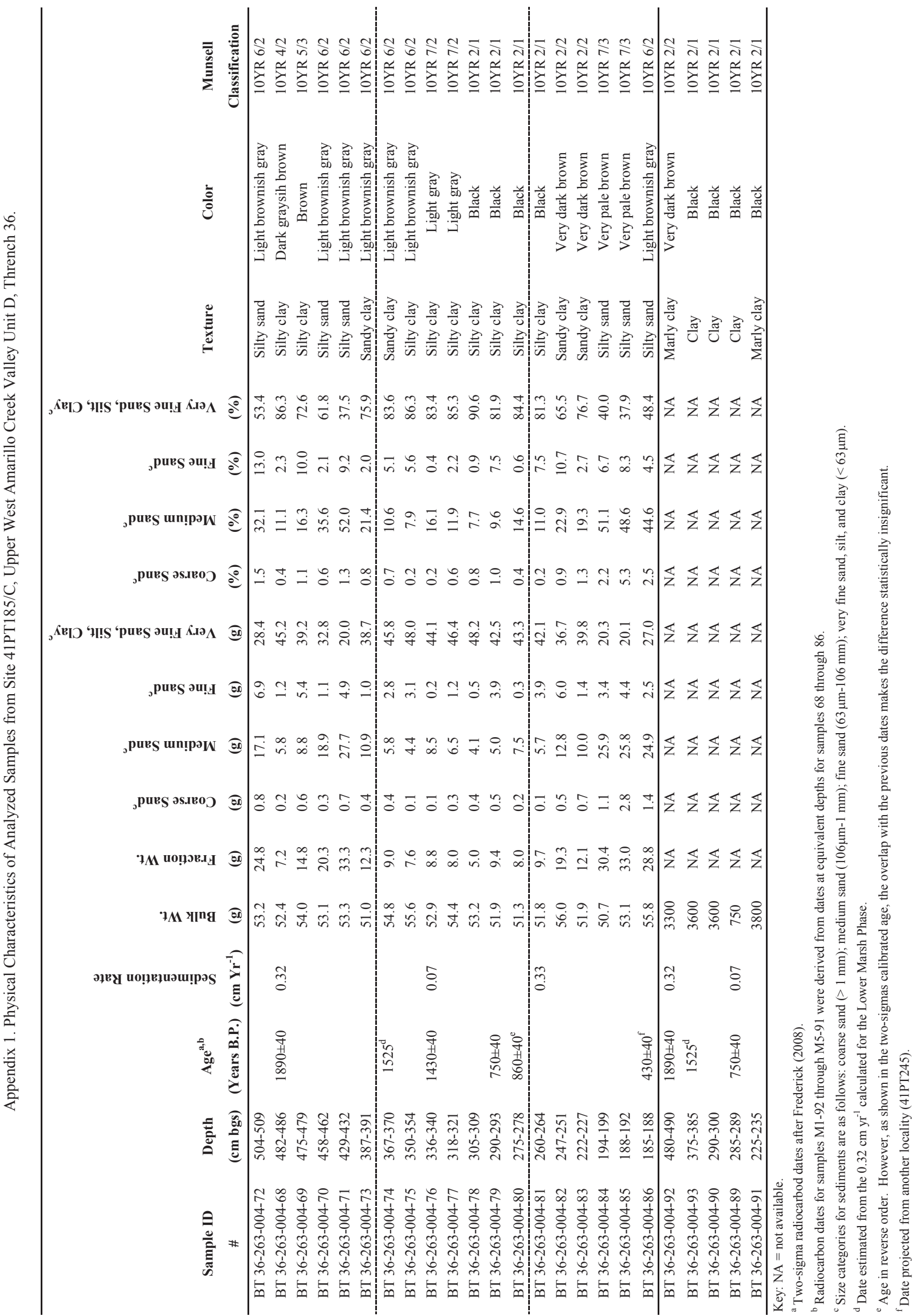




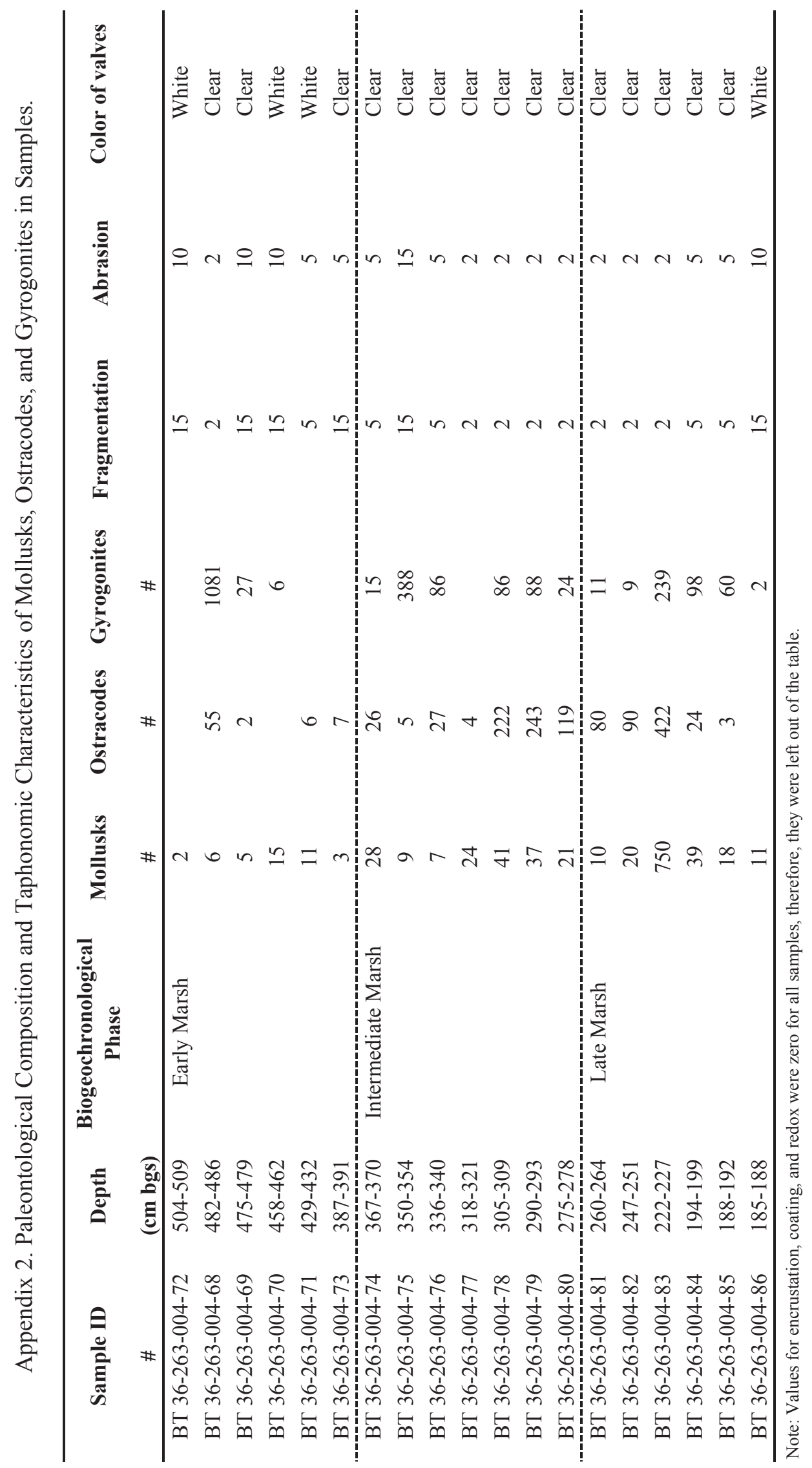




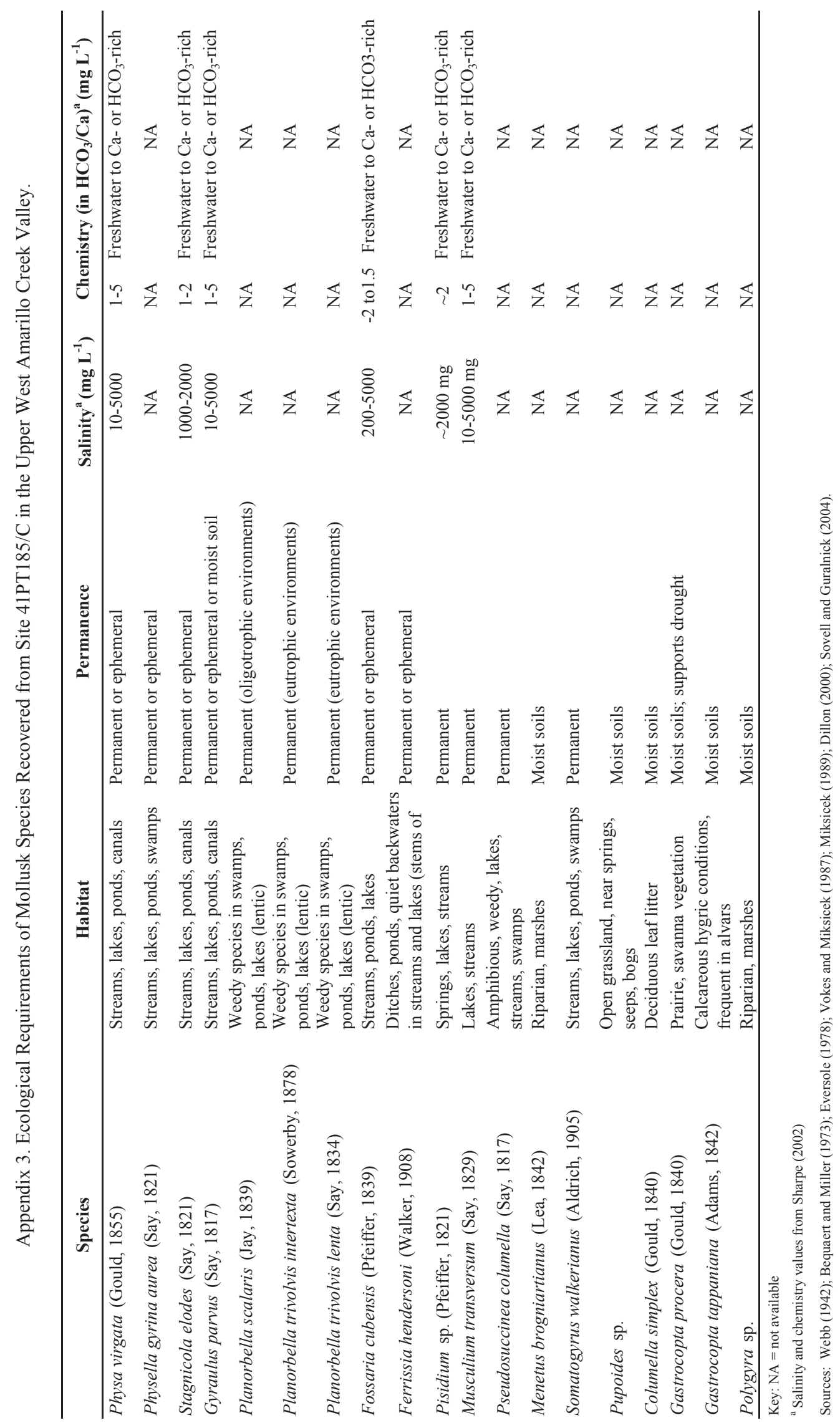




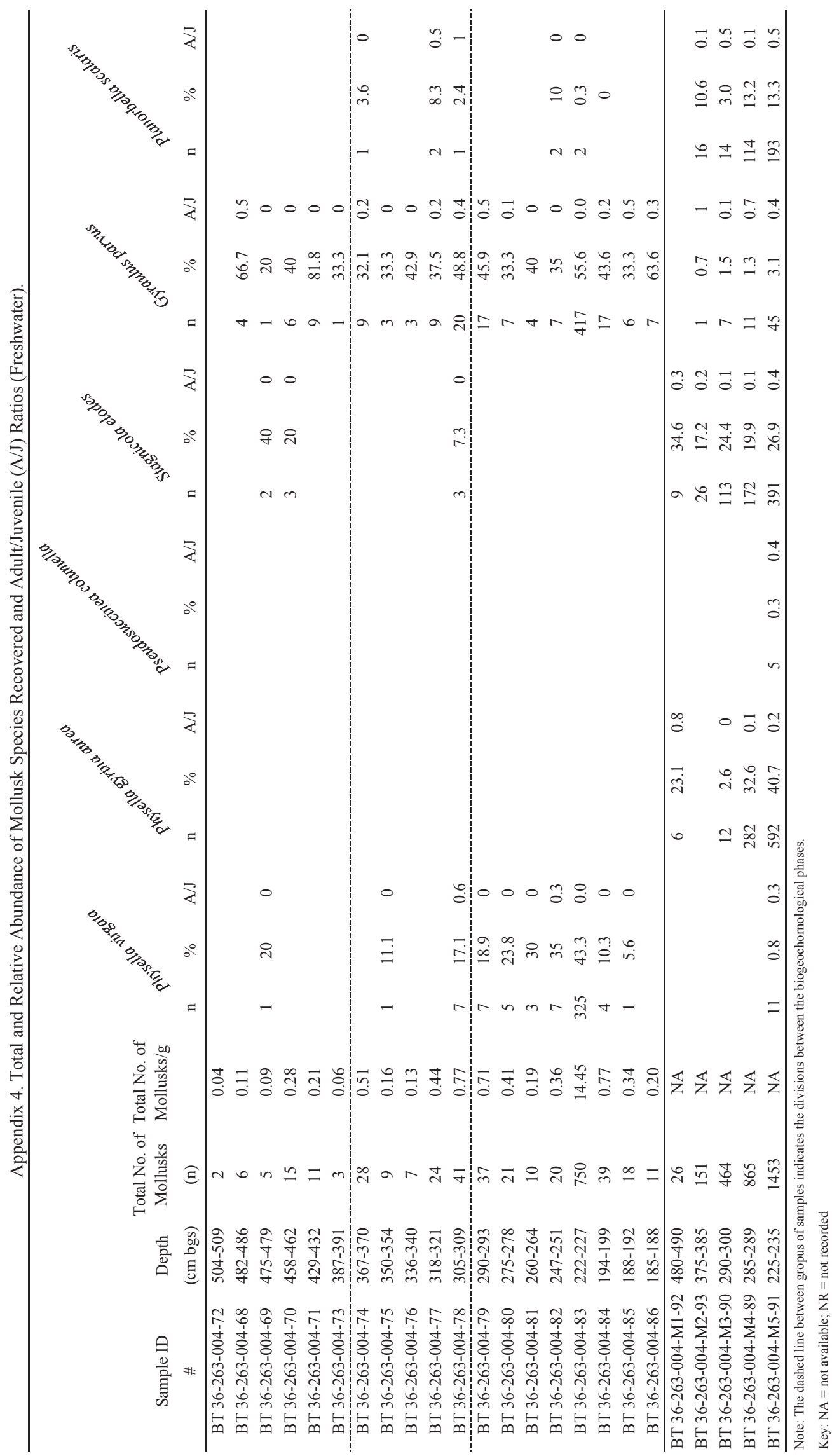




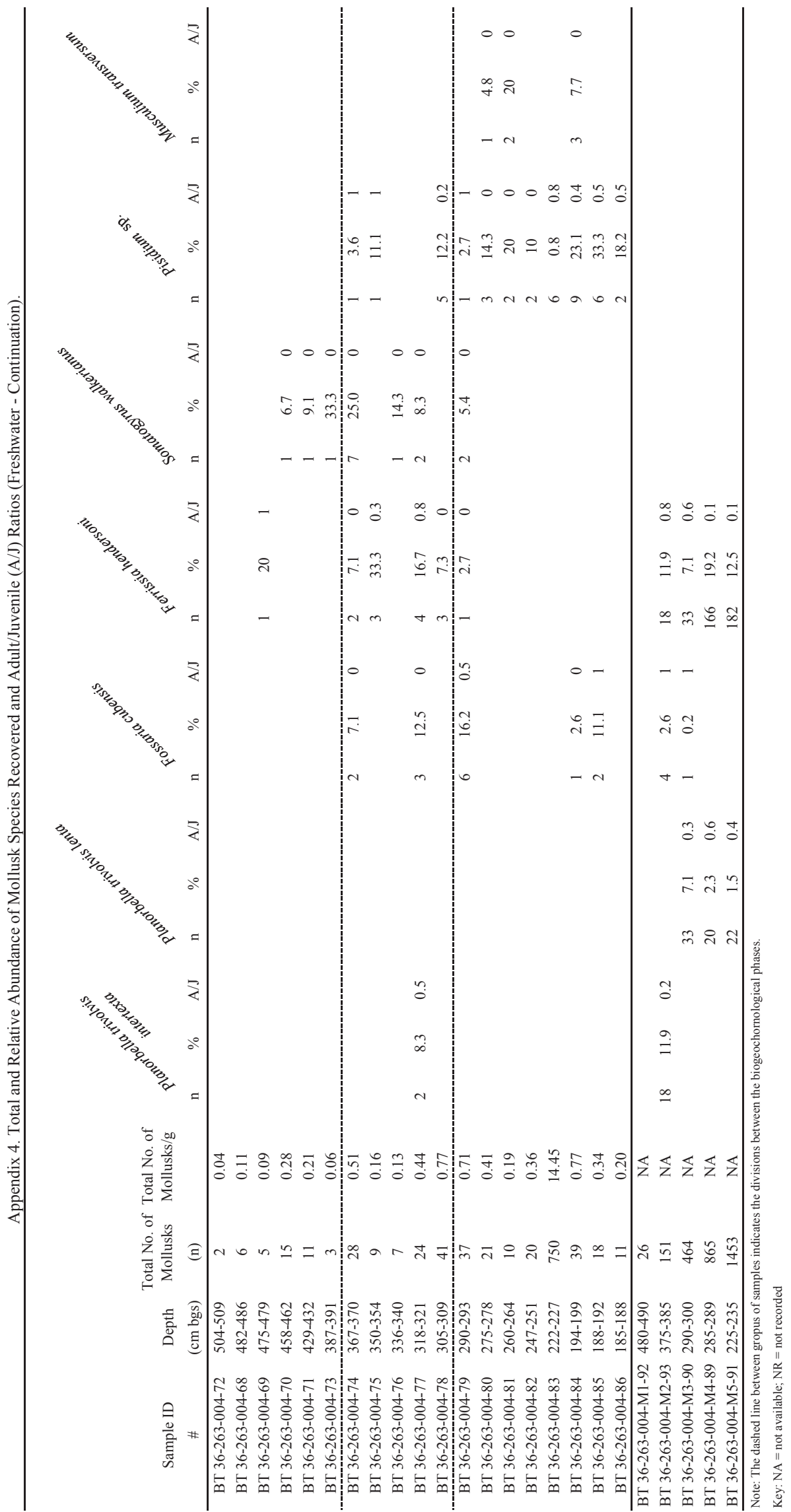




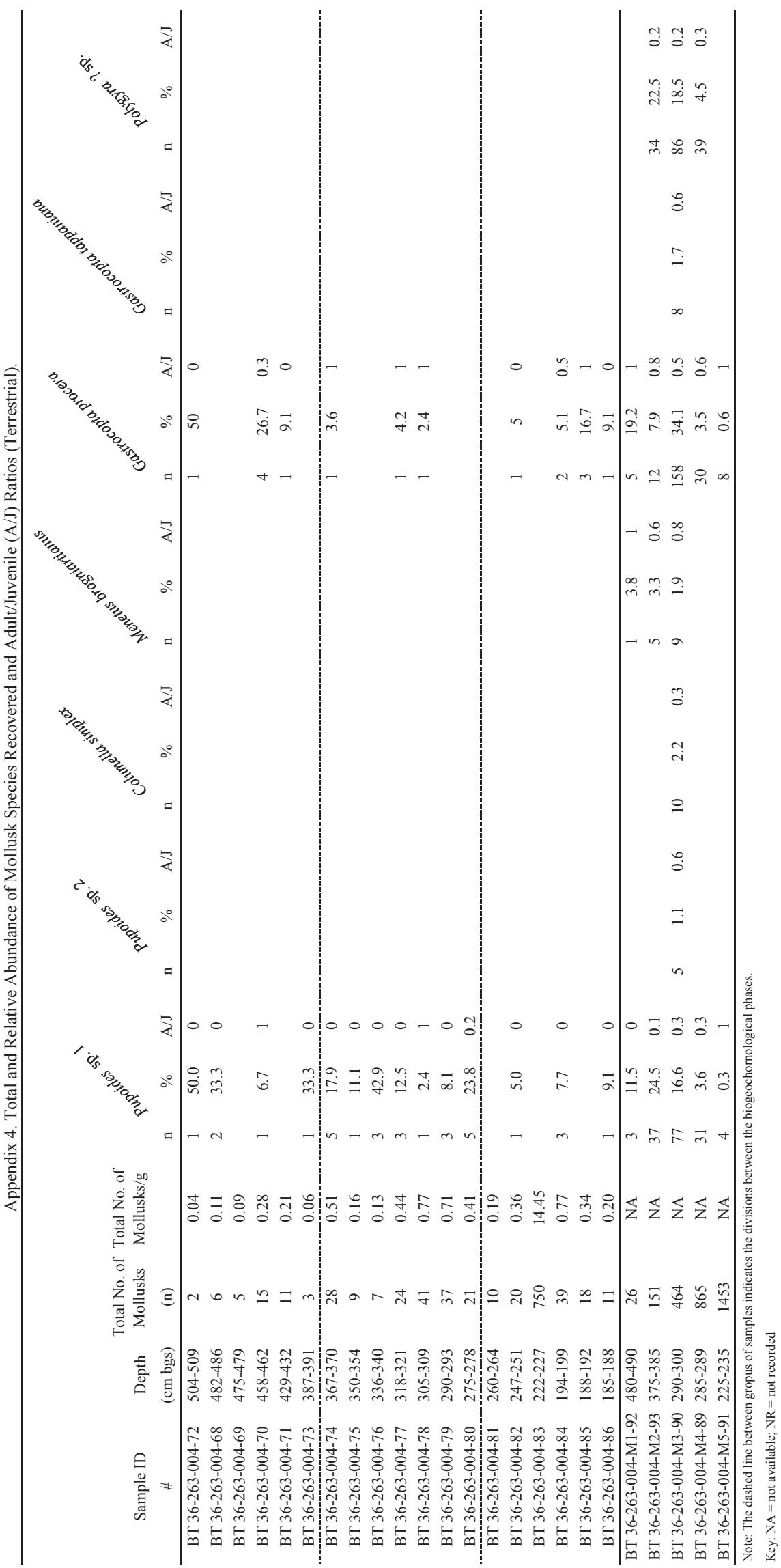




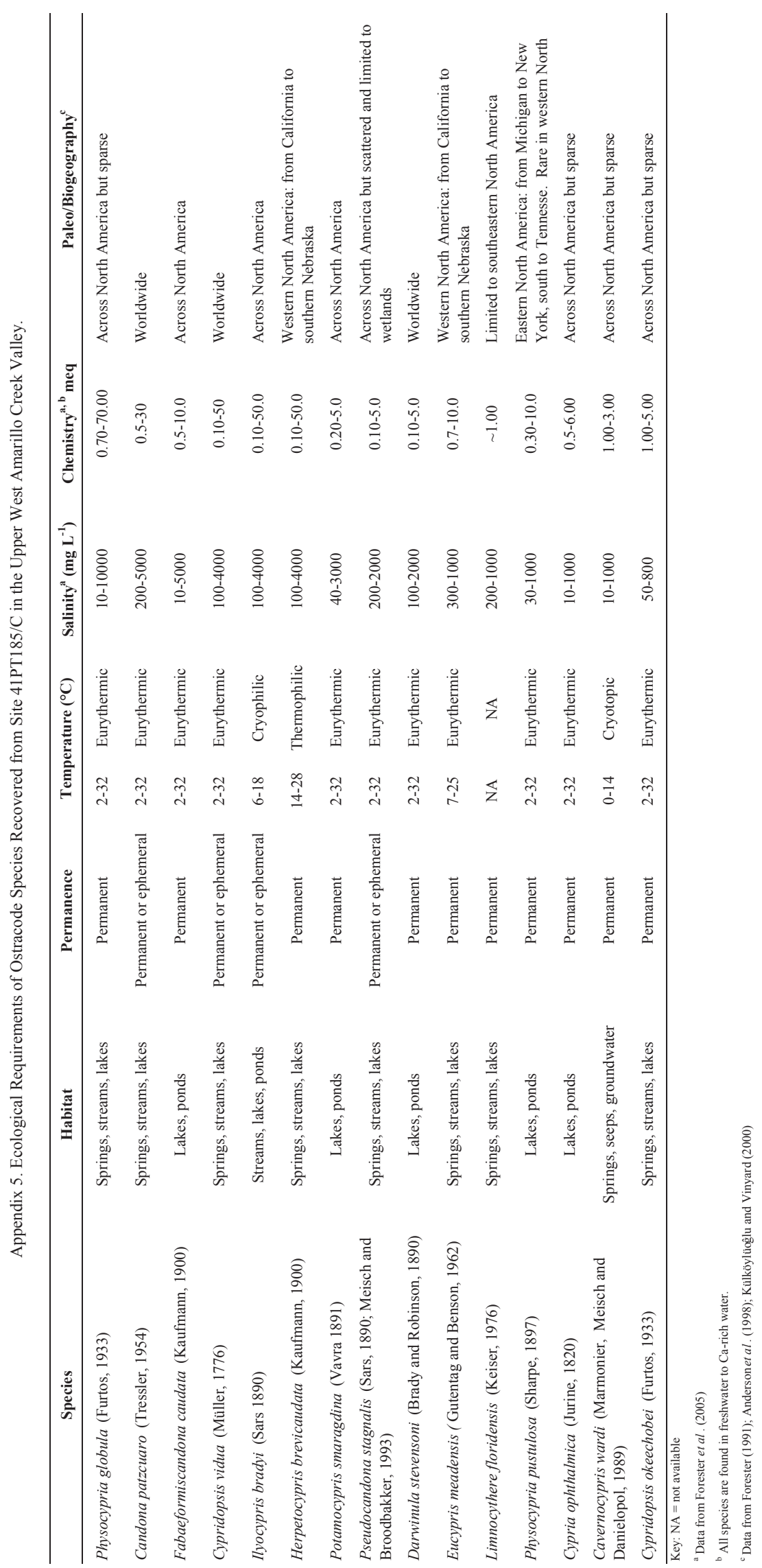




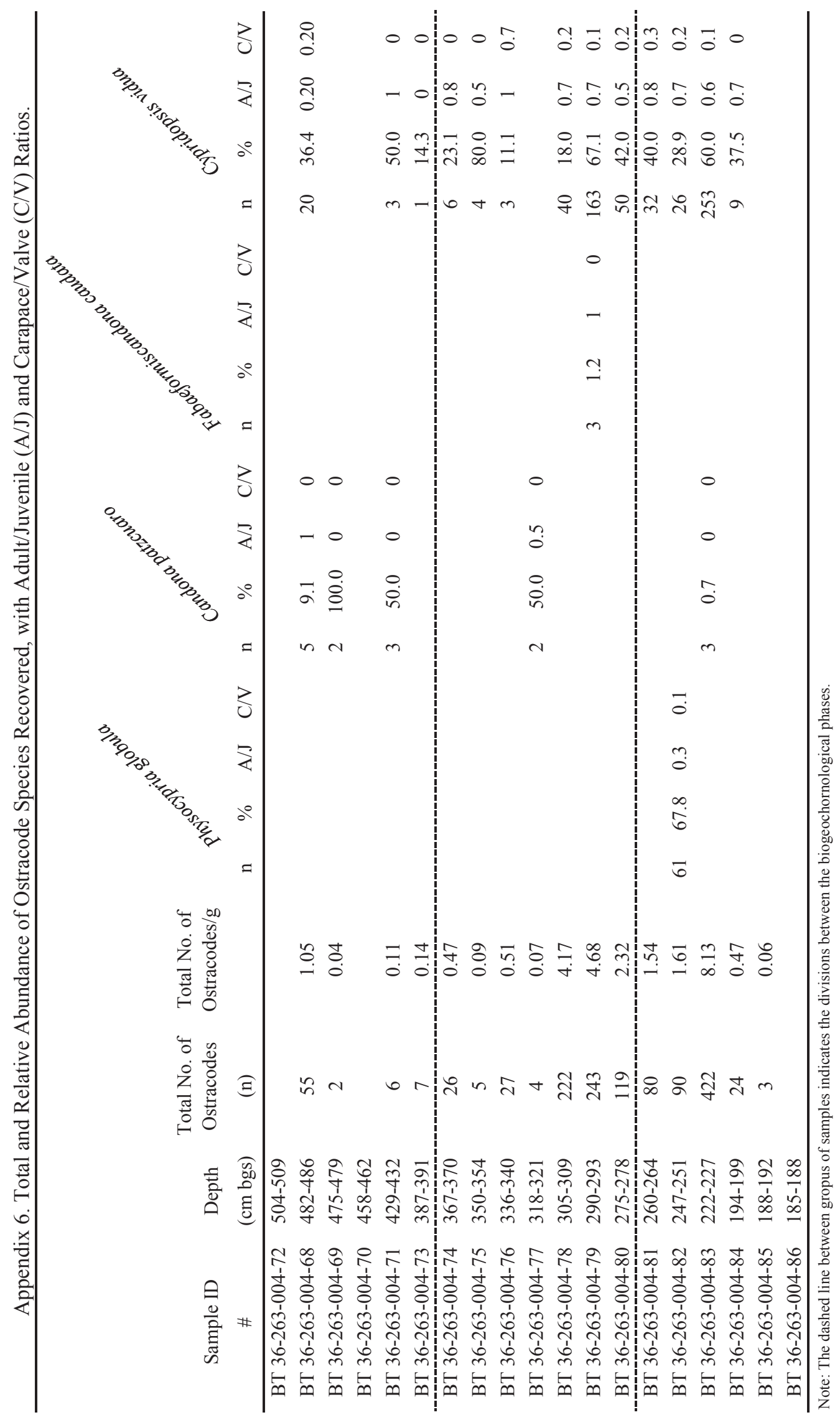




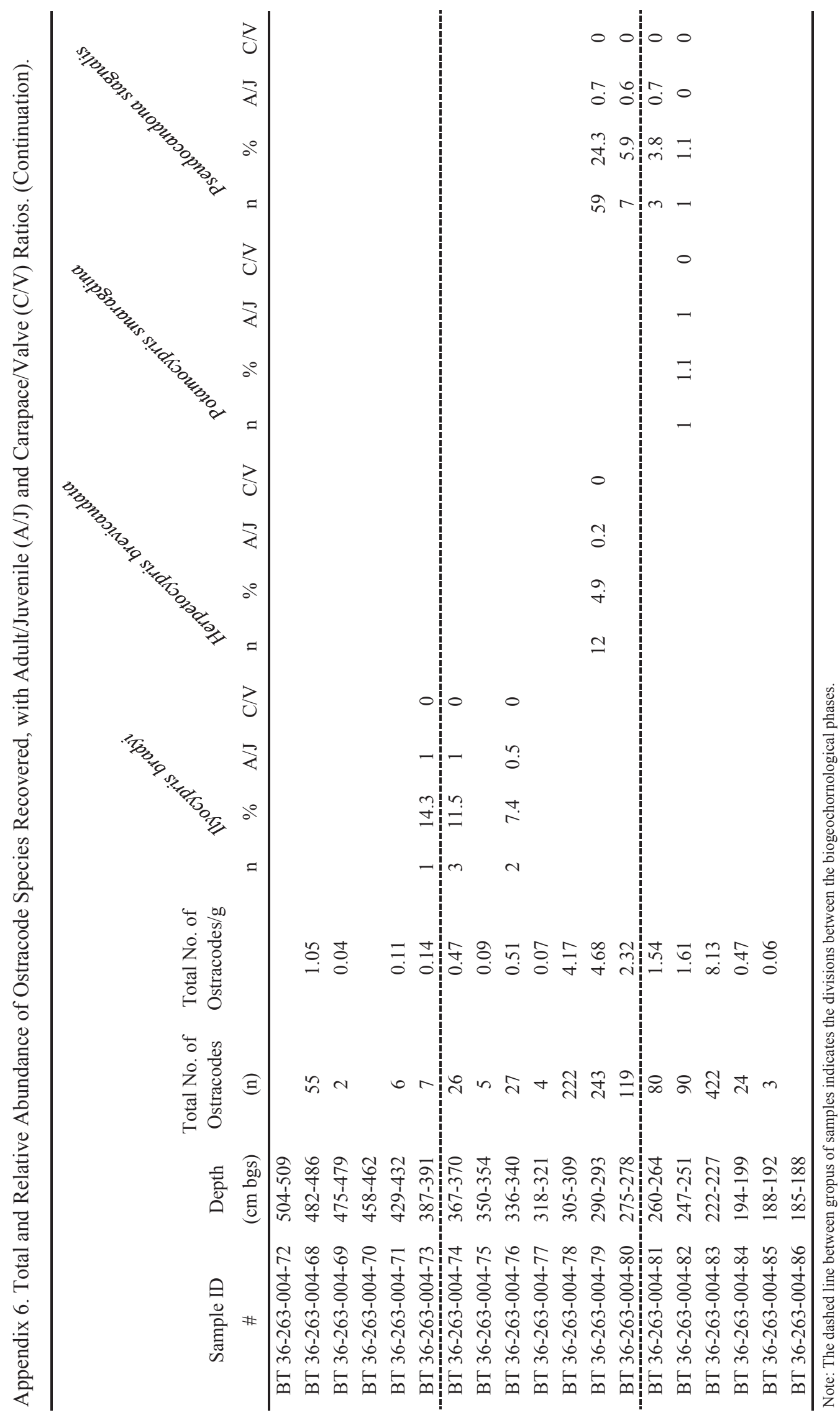




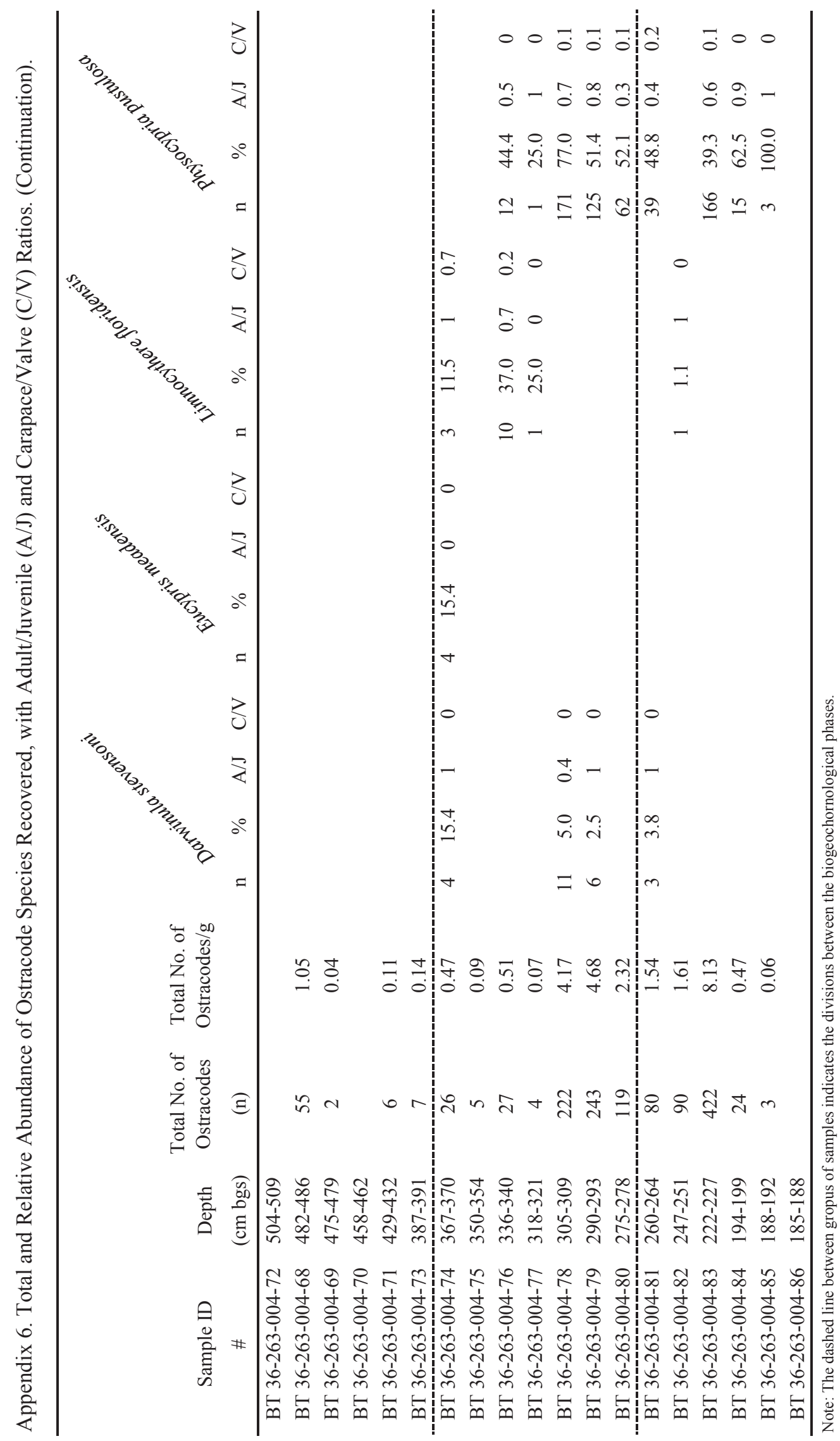




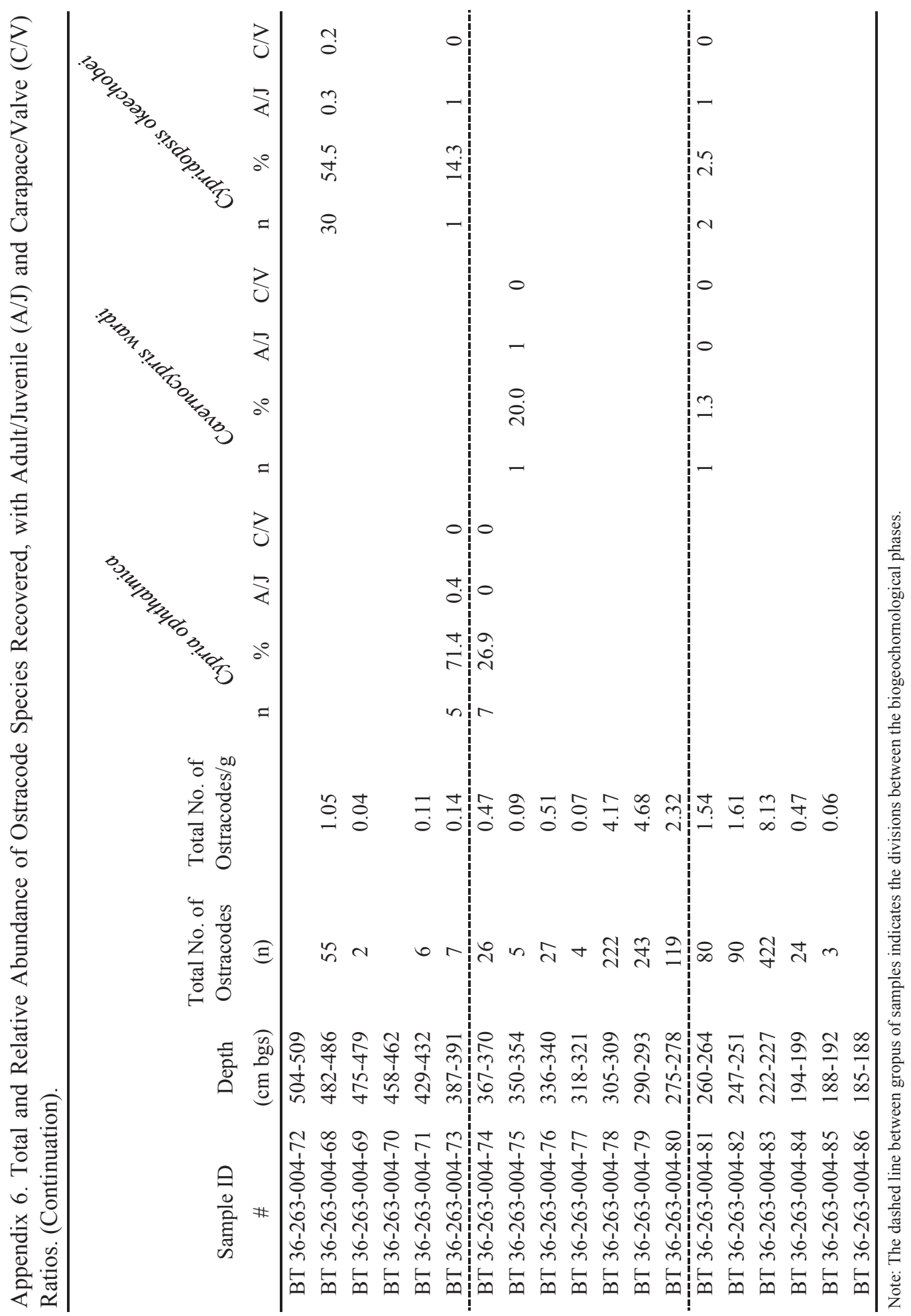


Appendix 7. Ecological Requirements of Charophyta Recovered from Site 41PT185/C in the Upper West Amarillo Creek Valley.

\begin{tabular}{|c|c|c|c|c|}
\hline Species & Habitat & Temperature & Optimal Seasonality & $\begin{array}{c}\mathrm{pH} \\
\text { Preference } \\
\end{array}$ \\
\hline Chara globularis Thuille & $\begin{array}{l}\text { High pH; Ca-rich waters, slow lentic or lotic } \\
\text { waters; occasionally in spring seeps; } \\
\text { intolerant to high nutrient conditions }\end{array}$ & $\begin{array}{l}5-25^{\circ} \mathrm{C} \\
\text { optimum: } \\
17^{\circ} \mathrm{C}-22^{\circ} \mathrm{C}\end{array}$ & $\begin{array}{l}\text { Mid-January to late September. Peak } \\
\text { between late April and mid-July }\end{array}$ & $\begin{array}{l}7.5-10.5 \\
\text { optimum: } \\
9.5-10.5\end{array}$ \\
\hline Chara filiformis (Hertsch) & $\begin{array}{l}\text { High pH; Ca-rich waters, slow lentic or lotic } \\
\text { waters; occasionally in spring seeps; } \\
\text { intolerant to high nutrient conditions }\end{array}$ & $\begin{array}{l}5-25^{\circ} \mathrm{C} \\
\text { optimum: } \\
17^{\circ} \mathrm{C}-22^{\circ} \mathrm{C}\end{array}$ & $\begin{array}{l}\text { Mid-January to late September. Peak } \\
\text { between late April and mid-July }\end{array}$ & $\begin{array}{l}7.5-10.5 \\
\text { optimum: } \\
9.5-10.5\end{array}$ \\
\hline Nitella flexilis (Linneaus, pro parte) & $\begin{array}{c}\text { Lower pH than Chara; slow lentic to lotic } \\
\text { waters; peaty bogs; intolerant to high nutrient } \\
\text { conditions }\end{array}$ & $\begin{array}{l}5-25^{\circ} \mathrm{C} \\
\text { optimum: } \\
13^{\circ} \mathrm{C}-18^{\circ} \mathrm{C}\end{array}$ & $\begin{array}{l}\text { Mid-January to late September. Peak } \\
\text { between late March and mid-June }\end{array}$ & $\begin{array}{l}7.5-10.5 \\
\text { optimum: } \\
7.5-9.0\end{array}$ \\
\hline
\end{tabular}

Note: All species are permanent or ephemeral; they prefer late spring to summer but may occur year-round.

Source: Coletta et al . (2001); Andrews et a l. (2004); Pentecost et al . (2006).

Appendix 8. Total and Relative Abundance of Charophyta Recovered from Site 41PT185/C in the Upper West Amarillo Creek Valley.

\begin{tabular}{|c|c|c|c|c|c|c|c|c|c|}
\hline Sample ID & Depth & $\begin{array}{l}\text { Total No. of } \\
\text { Gyrogonites }\end{array}$ & $\begin{array}{c}\text { Total No. of } \\
\text { Gyrogonites/g }\end{array}$ & & & & & & \\
\hline \# & (cm bgs) & (n) & & $\mathbf{n}$ & $\%$ & $\mathbf{n}$ & $\%$ & $\mathbf{n}$ & $\%$ \\
\hline BT 36-263-004-72 & $504-509$ & & & & & & & & \\
\hline ВТ $36-263-004-68$ & $482-486$ & 1081 & 20.63 & 721 & 66.7 & 360 & 33.3 & & 0 \\
\hline BT $36-263-004-70$ & $458-462$ & 6 & 0.11 & 6 & 100 & & 0 & & 0 \\
\hline BT 36-263-004-71 & $429-432$ & & & & & & & & \\
\hline BT 36-263-004-73 & $387-391$ & & & & & & & & \\
\hline BT 36-263-004-74 & $367-370$ & 15 & 0.27 & 9 & 60 & 6 & 40 & & 0 \\
\hline BT 36-263-004-75 & $350-354$ & 388 & 6.98 & & 0 & & 0 & 388 & 100 \\
\hline BT 36-263-004-76 & $336-340$ & 86 & 1.63 & & 0 & & 0 & 86 & 100 \\
\hline BT $36-263-004-77$ & $318-321$ & & & & & & & & \\
\hline BT $36-263-004-79$ & $290-293$ & 88 & 1.70 & 40 & 45.5 & 36 & 40.9 & 12 & 13.6 \\
\hline BT $36-263-004-80$ & $275-278$ & 24 & 0.47 & 22 & 91.7 & & 0 & 2 & 8.3 \\
\hline BT $36-263-004-81$ & $260-264$ & 11 & 0.21 & 7 & 63.6 & & 0 & 4 & 36.4 \\
\hline BT $36-263-004-82$ & $247-251$ & 9 & 0.16 & 7 & 77.8 & & 0 & 2 & 22.2 \\
\hline BT $36-263-004-83$ & $222-227$ & 239 & 4.61 & 199 & 83.3 & 40 & 16.7 & & 0 \\
\hline BT 36-263-004-84 & 194-199 & 98 & 1.93 & 71 & 72.4 & 18 & 18.4 & 9 & 9.2 \\
\hline BT 36-263-004-85 & $188-192$ & 60 & 1.13 & 44 & 73.3 & 11 & 18.3 & 5 & 8.3 \\
\hline BT 36-263-004-86 & $185-188$ & 2 & 0.04 & 2 & 100 & & 0 & & 0 \\
\hline
\end{tabular}

Note: The dashed line between gropus of samples indicates the divisions between the biogeochornological phases. 
Appendix 9. Stable-Isotope Data Obtained from the Ostracodes Cypridopsis vidua and Cypridopsis okeechobei .

\begin{tabular}{|c|c|c|c|c|c|c|c|c|c|c|}
\hline \multirow{2}{*}{$\begin{array}{c}\text { Sample ID } \\
\#\end{array}$} & \multirow{2}{*}{$\begin{array}{c}\text { Depth } \\
\text { (cm bgs) }\end{array}$} & \multirow[t]{2}{*}{ Species } & \multicolumn{4}{|c|}{$\delta^{13} \mathrm{C}$} & \multicolumn{4}{|c|}{$\delta^{18} \mathrm{O}$} \\
\hline & & & Replicate 1 & Replicate 2 & Average & Std. Dev. & Replicate 1 & Replicate 2 & Average & Std. Dev. \\
\hline BT 36-263-004-72 & $504-509$ & $-\cdots$ & & & & & & & & \\
\hline BT 36-263-004-68 & $482-486$ & Cypridopsis okeechoebi & -4.62 & -4.97 & -4.79 & 0.030 & -6.43 & -6.06 & -6.25 & 0.044 \\
\hline BT 36-263-004-69 & $475-479$ & $-\cdots$ & & & & & & & & \\
\hline BT 36-263-004-70 & $458-462$ & - & & & & & & & & \\
\hline BT 36-263-004-71 & $429-432$ & - & & & & & & & & \\
\hline BT 36-263-004-73 & $387-391$ & $\ldots$ & & & & & & & & \\
\hline BT 36-263-004-74 & $367-370$ & Cypridopsis vidua & -4.41 & -2.96 & -3.68 & 0.034 & -3.73 & -3.21 & -3.47 & 0.069 \\
\hline BT 36-263-004-75 & $350-354$ & - & & & & & & & & \\
\hline BT 36-263-004-76 & $336-340$ & Cypridopsis vidua & -3.58 & -3.45 & -3.52 & 0.085 & -6.59 & -5.27 & -5.93 & 0.114 \\
\hline BT 36-263-004-77 & $318-321$ & -- & & & & & & & & \\
\hline BT 36-263-004-78 & $305-309$ & Cypridopsis vidua & -2.35 & -2.18 & -2.27 & 0.044 & -3.45 & -4.84 & -4.14 & 0.057 \\
\hline BT 36-263-004-79 & $290-293$ & Cypridopsis vidua & -3.09 & -3.48 & -3.28 & 0.013 & -3.01 & -3.67 & -3.34 & 0.037 \\
\hline BT $36-263-004-80$ & $275-278$ & Cypridopsis vidua & -1.02 & 0.79 & -0.11 & 0.026 & -0.90 & 2.08 & 0.59 & 0.057 \\
\hline BT $36-263-004-81$ & $260-264$ & Cypridopsis vidua & -2.58 & -0.08 & -1.33 & 0.033 & -0.42 & -3.11 & -1.77 & 0.041 \\
\hline BT $36-263-004-82$ & $247-251$ & Cypridopsis vidua & 2.69 & 5.51 & 4.10 & 0.065 & -1.67 & -1.03 & -1.35 & 0.057 \\
\hline BT 36-263-004-83 & $222-227$ & Cypridopsis vidua & -3.59 & -2.31 & -2.95 & 0.044 & -3.18 & -2.34 & -2.76 & 0.045 \\
\hline BT 36-263-004-84 & 194-199 & Cypridopsis vidua & -2.15 & -1.97 & -2.06 & 0.050 & -4.09 & -5.99 & -5.04 & 0.078 \\
\hline BT 36-263-004-85 & $188-192$ & --- & & & & & & & & \\
\hline BT 36-263-004-86 & $185-188$ & $-\ldots$ & & & & & & & & \\
\hline
\end{tabular}

Appendix 10. Stable Isotope Data Obtained from Gyrogonites of Chara globularis and Nitella flexilis.

\begin{tabular}{|c|c|c|c|c|c|c|c|c|c|c|c|c|}
\hline \multirow{2}{*}{$\begin{array}{c}\text { Sample ID } \\
\#\end{array}$} & \multirow{2}{*}{$\begin{array}{c}\text { Depth } \\
\text { (cm bgs) }\end{array}$} & \multirow[t]{2}{*}{ Species } & \multicolumn{5}{|c|}{$\delta^{13} \mathrm{C}$} & \multicolumn{5}{|c|}{$\delta^{18} \mathrm{O}$} \\
\hline & & & Replicate 1 & Replicate 2 & Replicate 3 & Average & Std. Dev. & Replicate 1 & Replicate 2 & Replicate 3 & Average & Std. Dev. \\
\hline BT 36-263-004-72 & $504-509$ & $\cdots$ & & & & & & & & & & \\
\hline BT 36-263-004-68 & $482-486$ & Chara globularis & -6.70 & -6.35 & & -6.52 & 0.022 & -5.74 & -6.59 & & -6.17 & 0.056 \\
\hline BT 36-263-004-69 & $475-479$ & Chara globularis & -6.18 & -6.60 & & -6.39 & 0.022 & -6.59 & -6.77 & & -6.68 & 0.067 \\
\hline BT 36-263-004-70 & $458-462$ & $\cdots$ & & & & & & & & & & \\
\hline BT 36-263-004-71 & $429-432$ & -- & & & & & & & & & & \\
\hline BT $36-263-004-73$ & $387-391$ & $\ldots$ & & & & & & & & & & \\
\hline BT 36-263-004-75 & $350-354$ & Nitella flexilis & -12.83 & -13.47 & & -13.15 & 0.015 & -7.61 & -7.95 & & -7.78 & 0.068 \\
\hline BT 36-263-004-76 & $336-340$ & Nitella flexilis & -10.22 & -9.84 & & -10.03 & 0.027 & -6.97 & -7.04 & & -7.01 & 0.023 \\
\hline BT 36-263-004-77 & $318-321$ & -- & & & & & & & & & & \\
\hline BT 36-263-004-78 & 305-309 & Chara globularis & -2.37 & -3.65 & & -3.01 & 0.028 & -7.29 & -6.55 & & -6.92 & 0.060 \\
\hline BT 36-263-004-79 & $290-293$ & Chara globularis & -3.85 & -1.62 & & -2.74 & 0.025 & -3.57 & -6.40 & & -4.99 & 0.052 \\
\hline BT 36-263-004-80 & $275-278$ & Chara globularis & -4.38 & -3.17 & & $\begin{array}{r}-3.78 \\
-3.7 \\
\end{array}$ & 0.037 & -5.66 & -6.08 & & -5.87 & 0.049 \\
\hline BT 36-263-004-81 & $260-264$ & Chara globularis & -3.04 & & & -3.04 & 0.016 & -6.51 & & & -6.51 & 0.026 \\
\hline BT 36-263-004-82 & $247-251$ & $-\cdots$ & & & & & & & & & & \\
\hline BT 36-263-004-84 & 194-199 & Chara globularis & -1.24 & -1.45 & -1.74 & -1.48 & 0.034 & -6.05 & -7.24 & -6.87 & -6.72 & 0.059 \\
\hline BT 36-263-004-85 & 188-192 & Chara globularis & -2.11 & -2.15 & & -2.13 & 0.023 & -5.47 & -5.99 & & -5.73 & 0.045 \\
\hline BT 36-263-004-86 & 185-188 & $-\cdots$ & & & & & & & & & & \\
\hline
\end{tabular}




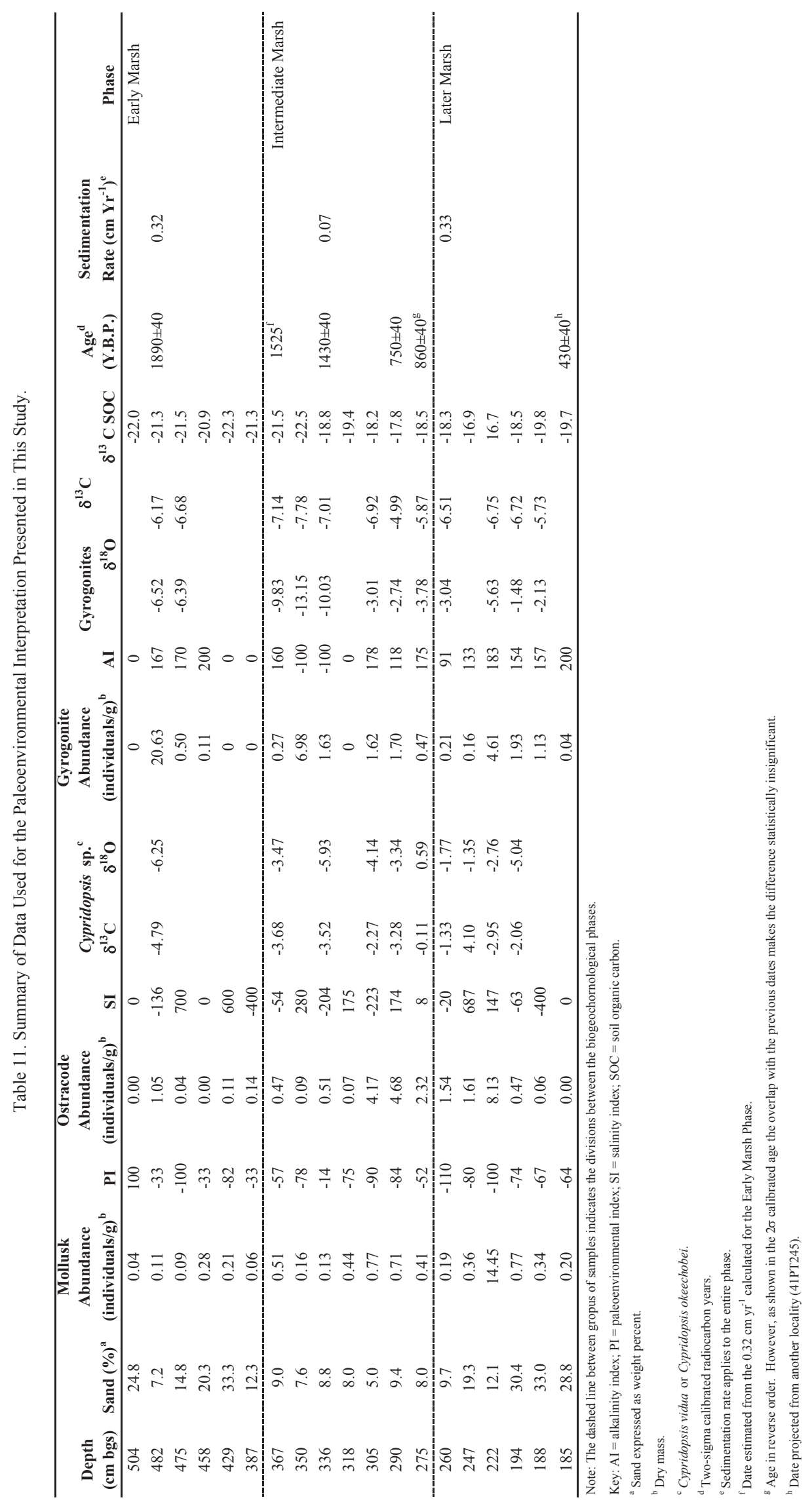

